\title{
Calcium Release at Fertilization: Artificially Mimicking the Oocyte's Response to Sperm
}

\author{
Christopher G. GRUPEN ${ }^{1)}$, Mark B. NOTTLE') and Hiroshi NAGASHIMA ${ }^{2)}$ \\ 1) Reproductive Biotechnology Division, BresaGen Limited, P.O. Box 259, Rundle Mall, \\ Adelaide, SA 5000, Australia, ${ }^{2}$ Laboratory of Reproduction Engineering, Meiji University, \\ Kawasaki, Yokohama 214-5871, Japan
}

\begin{abstract}
The mechanism of sperm-induced calcium release has been the subject of many studies since the development in the late 1950s of in vitro culture systems that support mammalian fertilization. Despite efforts to elucidate the nature of the signal from the sperm that triggers both the early and late events of oocyte activation, the precise mechanism remains unresolved. Now, with the advent of somatic nuclear transfer technologies, the need to better understand this unique process has been recognised. Nuclear transfer embryos must be induced to commence development artificially because the activating signal from the sperm is absent. The primary activating stimulus is a large increase in the concentration of intracellular-free calcium and numerous physical and chemical treatments have been found to induce calcium changes that initiate the events of oocyte activation. Although live cloned offspring have been produced in a number of species, the overall efficiencies of the nuclear transfer procedures described thus far are unacceptably low and phenotypic anomalies are common. With the aim of improving these efficiencies, researchers are developing artificial activation treatments which induce oocyte responses that mimic those induced by fertilizing sperm. One strategy is to replicate the pattern of calcium change more closely. Another strategy is to couple an activating stimulus with treatments that inhibit maturation (or M-phase) promoting factor (MPF) activity, which regulates meiotic progression in oocytes. This paper reviews what is understood of calcium release at fertilization and describes the treatments that have been used to induce oocyte activation artificially in parthenogenetic and nuclear transfer studies. The relative effectiveness of the strategies employed to mimic the oocyte's response to sperm are discussed.
\end{abstract}

Key words: Oocyte activation, Fertilization, Parthenogenesis, Nuclear transfer

(J. Reprod. Dev. 48: 313-333, 2002)

$\mathbf{T}$ o produce a viable embryo at fertilization, the sperm not only provides the male chromosomal complement, but also the stimulus that initiates development. The mechanism by which the activating signal is transmitted from the sperm to the oocyte is not fully clarified, but it is clear that this signal triggers a large increase in the concentration of intracellular-free calcium. In fertilized sea urchin and Xenopus eggs, the calcium

Accepted for publication: April 17, 2002

Correspondence: C. G. Grupen increase takes the form of a propagating wave that originates at the point of sperm attachment and traverses the egg at a velocity of 5 to $10 \mu \mathrm{m} / \mathrm{sec}$ [1]. Studies in the hamster [2], mouse [3], cow [4] and pig [5] demonstrate that mammalian oocytes display a similar increase of intracellular calcium at fertilization, but that the initial transient rise is followed by a series of smaller transient increases. The frequency of the calcium transient increases, or oscillations, varies among species, occurring at intervals of 1 to $10 \mathrm{~min}$ in hamster oocytes [4] and 
15 to $51 \mathrm{~min}$ in cattle oocytes [2]. These patterns of sperm-induced calcium oscillations can continue in mammalian oocytes for several hours after fertilization [1]. The precise role of the additional calcium spikes during mammalian fertilization remains unclear. Some evidence suggests that the multiple calcium rises may be involved in the regulation of later developmental events, such as compaction and blastocyst formation [6-9].

The ability of the oocyte to release calcium in response to the fertilizing sperm increases during oogenesis [10]. In mature mouse oocytes, the first sperm-induced calcium transient increase is much larger in amplitude and longer in duration than in immature oocytes [11]. In addition, fertilization of immature mouse oocytes only generates two or three calcium oscillations, which cease within $1 \mathrm{~h}$, compared with the highly repetitive series of calcium oscillations lasting 2 to $3 \mathrm{~h}$ in mature oocytes [12]. The modifications in the calcium release response during oocyte maturation may be due to an increase in the size of the internal calcium store or an increase in the density of the calcium channels [10]. There is evidence that the cell cycle plays an important role in the acquisition of these changes and that the oocyte must be in the metaphase stage of the cell cycle at fertilization in order to generate a normal calcium release response [13].

\section{Calcium Release Mechanisms}

The mechanism(s) by which calcium release is mediated at fertilization has been the subject of many studies. Calcium release mechanisms that have been found to exist in mammalian oocytes include those that are regulated by inositol trisphosphate receptors, ryanodine receptors and calcium itself.

\section{Inositol trisphosphate receptors}

Many cellular processes, including cell growth, transformation, secretion, smooth muscle contraction, sensory perception and neuronal signalling, result in an increase of intracellular calcium [14]. In the majority of these systems, external stimuli, such as neurotransmitters, hormones and growth factors, interact with cell surface receptors that are coupled to mechanisms which activate phospholipase C (PLC) to hydrolyze an inositol lipid precursor stored in the plasma membrane. The hydrolysis of this lipid precursor, phosphatidylinositol 4,5-bisphosphate $\left(\mathrm{PIP}_{2}\right)$, releases inositol 1,4,5-trisphosphate $\left(\mathrm{InsP}_{3}\right)$ into the cytoplasm which then binds to $\mathrm{Ins}_{3}$ receptors (InsP ${ }_{3} \mathrm{Rs}$ ) (see Fig. 1). The InsP $\mathrm{P}_{3} \mathrm{R}$ functions as a major intracellular calcium channel and is normally located in portions of the endoplasmic reticulum (ER). Upon binding InsP $\mathrm{P}_{3}$, the receptor undergoes a conformational change which opens the channel, thereby mobilizing calcium from internal stores [14]. The InsP $\mathrm{P}_{3} \mathrm{Rs}$ are abundant in mammalian oocytes and have been shown to mediate calcium release during maturation in mouse [10], hamster [15] and cattle oocytes [16] and to generate calcium oscillations during fertilization in hamster [17] and cattle oocytes [4]. Furthermore, ooplasmic redistribution and an increase in the amount of this receptor during maturation have been correlated with an increased ability to release calcium at the metaphase-II (M-II) stage [16, 18, 19].

\section{Ryanodine receptors}

In muscle cells, calcium release is predominantly mediated by ryanodine receptors (RyRs), which are primarily associated with the sarcoplasmic reticulum (SR) [14]. The RyR mobilizes calcium from internal stores in response to the plant alkaloid ryanodine and reagents such as caffeine, cyclic adenosine diphosphate ribose (cADPR) and fatty acid derivatives [20]. Although the RyR is almost twice as large as the $\operatorname{Ins}_{3} \mathrm{R}$ they share considerable structural and functional similarities [21]. Both receptors are tetrameric, with the membrane-spanning C-terminal regions of each monomer combining to form the calcium channel, and the large $\mathrm{N}$-terminal domains presenting the binding sites to the cytosol [14]. The remarkable structural similarities and the regions of sequence homology that exist between the RyRs and $\mathrm{InsP}_{3} \mathrm{Rs}$ suggest they have a common evolutionary origin. Like the InsP $\mathrm{P}_{3} \mathrm{Rs}$, RyRs are present in mammalian oocytes and have been shown to mediate calcium release in mouse [12, 22], cattle [23, 24], pig [25] and human [26] oocytes.

Even though the existence of both $\mathrm{InsP}_{3} \mathrm{Rs}$ and RyRs in mammalian oocytes has been established $[23,25,27]$, several lines of evidence suggest that the release of calcium at fertilization is most likely induced by $\mathrm{InsP}_{3}[10]$. Firstly, sperm-induced calcium oscillations were completely blocked in 
hamster oocytes injected with a monoclonal antibody to the Ins $\mathrm{P}_{3} \mathrm{Rs}$ [28]. Secondly, mouse oocytes injected with a monoclonal antibody that binds to the InsP $P_{3}$ Rs failed to exhibit both early and late events of oocyte activation following insemination [29]. Thirdly, the density of the RyRs is reported to be as much as 100-fold lower than that of the $\mathrm{InsP}_{3} \mathrm{Rs}$ in cattle oocytes [16]. Finally, in mouse oocytes, expression of the type I isoform of the Ins $\mathrm{P}_{3} \mathrm{R}$ protein was found to increase during oocyte maturation and decrease dramatically within $8 \mathrm{~h}$ of fertilization [30]. The contribution of the RyRs to calcium release at fertilization, if any, has not yet been established.

\section{Calcium-induced calcium release}

The repetitive pattern of calcium transient increases observed in mammalian oocytes in response to fertilizing sperm is also displayed in many of the cells that respond to calciummobilizing stimuli [14]. A regenerative process of calcium-induced calcium release (CICR) drives the generation of each calcium spike [21]. Another functional property shared by the RyRs and the InsP $\mathrm{P}_{3} \mathrm{Rs}$, which is responsible for both the spatial and temporal patterns of calcium signalling, is their variation in sensitivity in response to intracellularfree calcium [14]. A generalized CICR model of calcium spiking proposes that when internal calcium stores carrying RyRs or InsP $\mathrm{P}_{3} \mathrm{Rs}$ are charged with calcium, the sensitivity of the receptors is increased. Calcium channels nearest to the site of the external stimulus open in response to a relatively small increase in agonist levels, releasing calcium into the cytosol. This localized calcium increase mediates a progressive release of calcium from neighbouring stores by the CICR process, propagating a "wave" of calcium increase throughout the cell. Once the cytosolic calcium reaches a threshold level it then inhibits further calcium release by exerting a negative feedback effect on the calcium channels. Calcium is then pumped out of the cytoplasm by active transport and the internal calcium stores are recharged. An influx of extracellular calcium, through calcium channels located in the plasma membrane, is also required to help replenish the internal stores of calcium.

\section{Transduction of the Activating Signal}

At fertilization of the mammalian oocyte, the sperm first binds to and then fuses with the oocyte plasma membrane. The interaction between the gamete membranes activates specific biochemical pathways within the oocyte, which triggers the release of calcium. There has been a great deal of debate as to whether fusion of the gamete plasma membranes is a prerequisite for oocyte activation, or whether binding of the sperm to cell surface receptors can initiate oocyte activation. Consequently, the two hypotheses that have been proposed to explain how the activating signal is transmitted from the sperm to the oocyte are based on cell surface receptor-mediated signalling pathways and cytosolic sperm factor-mediated signalling pathways (see Fig. 1).

\section{Receptor-mediated signalling pathways}

At fertilization, an increase in $\operatorname{InsP}_{3}$ may be triggered by the sperm binding to surface receptors in the oocyte plasma membrane. There are two major receptor-mediated pathways that activate PLCs by separate transducing mechanisms to stimulate the formation of $\mathrm{InsP}_{3}$. One pathway is initiated by receptors that are coupled to $G$ proteins (or guanine nucleotide-binding proteins) and the other by receptors that activate tyrosine kinases directly or indirectly [14].

Members of the $G$ protein family transduce signals from receptors at the cell surface to internal cellular components by activating PLC- $\beta 1$, a PLC isozyme [14]. The activation of PLC- $\beta 1$ by G proteins requires energy in the form of guanosine triphosphate (GTP), which is hydrolyzed to guanosine diphosphate (GDP) in the process [14]. The theory that sperm-induced calcium release is mediated by G protein-linked receptors is supported by several studies that have examined the effects of $G$ protein activators and inhibitors on oocytes. For example, injection of the metabolically stable GDP analogue, guanosine-5'-O-(2thiodiphosphate) (GDP $\gamma \mathrm{S})$, inhibited intracellular calcium oscillations in fertilized hamster [31] and rabbit [32] oocytes and blocked $G$ protein-mediated calcium release in porcine oocytes [33]. Conversely, injection of guanosine-5'-O-(3thiotrisphosphate) (GTP $\gamma$ ), a hydrolysis-resistant analogue of GTP, caused repetitive intracellular calcium increases in unfertilized hamster [31, 34] 


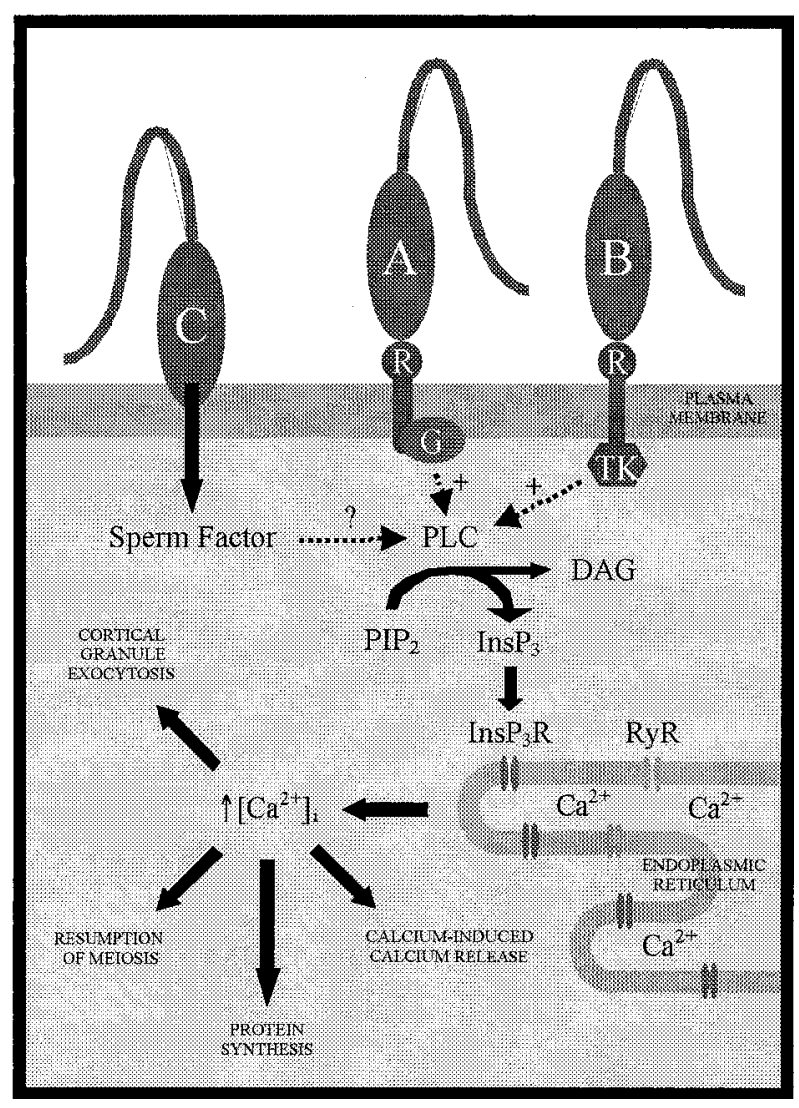

Fig. 1. The proposed mechanisms of sperm-induced calcium release in mammalian oocytes include receptor-mediated and sperm factor-mediated signalling pathways. Sperm (A, B) binds to a receptor $(R)$ that is linked to either a $G$ protein $(G)$ or tyrosine kinase (TK), which activates $(+)$ phospholipase C (PLC). Alternatively, sperm (C) fuses with the oocyte plasma membrane and releases a sperm factor into the cytoplasm that may stimulate, or have, PLC activity (?). A component of the plasma membrane, phosphatidylinositol 4,5-bisphosphate $\left(\mathrm{PIP}_{2}\right)$, is hydrolysed by PLC to inositol 1,4,5trisphosphate $\left(\mathrm{InsP}_{3}\right)$ and diacylglycerol (DAG). The second messenger $\operatorname{InsP}_{3}$ then binds to its receptor $\left(\operatorname{Ins} \mathrm{P}_{3} \mathrm{R}\right)$, releasing calcium from internal stores and increasing the concentration of intracellular-free calcium $\left(\uparrow\left[\mathrm{Ca}^{2+}\right]_{i}\right)$. This calcium increase induces cellular events that are critical to the activation process. The ryanodine receptor (RyR) may mediate calcium-induced calcium release.

and rabbit [32] oocytes. Treatment with serotonin and carbochol, specific activators of $G$ proteins, also triggered calcium oscillations in hamster [34] and mouse [22] oocytes.

Later events associated with fertilization, such as cortical granule exocytosis, pronuclear formation and embryo development to the blastocyst stage, were evoked in porcine oocytes injected with GTP $\gamma S$ [35]. In contrast, pronuclear formation and cleavage to the 2-cell embryo stage were inhibited in fertilized mouse oocytes injected with $G$ protein inhibitors [36]. Finally, in oocytes expressing the $G$ protein-coupled muscarinic receptor, treatment with acetylcholine, the receptor's agonist, stimulated a variety of fertilization-related events including pronuclear formation [37]. Together, these findings clearly demonstrate that the G protein signal transducing mechanism exists in mammalian oocytes, but direct involvement of this pathway at fertilization has not been shown.

The signalling pathway could be mediated by sperm binding to receptors that are instead coupled to tyrosine kinases. Tyrosine kinases can generate InsP $P_{3}$ by activating PLC- $\gamma 1$, another PLC family member, in a phosphorylation process that requires adenosine triphosphate (ATP) [14]. Growth factors, such as platelet-derived growth factor (PDGF) and epidermal growth factor (EGF), engage two receptors, bringing them together to form a dimer. Each receptor contains a cytoplasmic tyrosine kinase domain that phosphorylates the other on specific tyrosine residues, thus enabling PLC $-\gamma 1$ to dock with the receptor and in turn be phosphorylated.

Tyrosine kinase activity has been demonstrated in sea urchin eggs following fertilization [38, 39] and stimulation of the EGF receptor tyrosine kinase activity induces a calcium wave in Xenopus eggs [40]. In mouse oocytes, fertilization results in the increased phosphorylation of a set of proteins, predominantly on tyrosine residues [41]. Immunodetection of PLC proteins using monoclonal antibodies reveals that PLC- $\gamma 1$, which is activated by tyrosine phosphorylation, is present in mature mouse oocytes and spermatozoa [42]. Finally, a role for tyrosine kinases at fertilization is supported by the finding that preincubation of mouse oocytes with tyrosine kinase inhibitors significantly hinders the normal sperm-induced calcium release response [42].

Integrins are a major family of cell adhesion receptors that have been implicated in the binding and fusion of sperm and oocyte plasma membranes [43]. Several integrins have been detected on the surface of mammalian oocytes [44-47], and characterization of the sperm transmembrane protein fertilin has revealed the presence of a "disintegrin" domain that may bind integrins [48]. 
Peptide analogues of the disintegrin domain and an antibody against the $\alpha 6$ integrin subunit inhibit sperm-oocyte binding and fusion in the mouse [44, 45]. Studies in many cell types have shown that integrin stimulation can induce tyrosine phosphorylation and increase the intracellular-free calcium concentration [49]. Furthermore, peptides containing the Arg-Gly-Asp (RGD) sequence, which is known to bind integrins, induced calcium release, cortical granule exocytosis and resumption of meiosis in Xenopus eggs [50].

\section{Sperm factor-mediated signalling pathway}

Although the evidence in support of a receptormediated signalling pathway is persuasive, a number of findings suggest that the signal transduction mechanism which triggers calcium release in response to sperm binding operates through a sperm factor-mediated signalling pathway. This mechanism requires the oocyte and sperm plasma membranes to fuse, and for an aqueous pore between the gamete cytoplasms to form that allows a cytosolic factor to diffuse from the sperm to the oocyte. Upon entering the oocyte, the sperm factor is hypothesized to mediate calcium release directly or indirectly. In sea urchin eggs, it has been found that sperm-egg fusion is essential for fertilization to take place, and the formation of an aqueous pore between the egg and sperm cytoplasm has been demonstrated [1]. Further support for this hypothesis comes from the finding that sperm-oocyte fusion precedes the initial intracellular calcium increase in mouse oocytes by 1 to $3 \mathrm{~min}$ [51].

The results of experiments in which putative activating messengers have been injected into oocytes indicate that the sperm factor cannot be calcium itself, nor can it be $\operatorname{InsP}_{3}$, cADPR or cyclic guanosine monophosphate (cGMP) [1]. At present, the most promising candidate messenger is a protein factor isolated from the cytosol of hamster and boar sperm [52]. Injection of this factor into hamster oocytes has been shown to trigger a series of calcium transient increases identical to those seen at fertilization [52]. Cytosolic sperm extracts also stimulated repetitive calcium oscillations following injection into mouse [53-55], cattle [56] and human [57] oocytes. Interestingly, injection of the same porcine sperm extract induced calcium oscillations of high frequency in mouse oocytes and low frequency in cattle oocytes, similar to the patterns of calcium release observed in each species at fertilization [56]. Later events associated with fertilization, such as pronuclear formation and cleavage, have also been induced in rabbit [58], mouse [55] and cattle [59] oocytes injected with a protein factor obtained from sperm.

Injection of intact sperm directly into the cytoplasm of human oocytes, or intracytoplasmic sperm injection (ICSI), induces calcium increases after a lag period of 4 to $12 \mathrm{~h} \mathrm{[60]} \mathrm{and} \mathrm{results} \mathrm{in} \mathrm{the}$ birth of normal offspring [61-63]. These results indicate that the fusion of sperm and oocyte plasma membranes can be bypassed, and that the stimulus responsible for activating the oocyte is probably due to a delayed release of a factor from the injected sperm. In the mouse, the amount or activity of this factor appears to increase during spermiogenesis because testicular spermatozoa induced pronuclear formation when injected into oocytes, whereas round spermatids did not [64]. In isolated heads of mature mouse and hamster epididymal spermatozoa, the factor is apparently associated with the perinuclear material [65]. Round spermatids by themselves can not induce calcium release when injected into mature oocytes [66], but can still give rise to normal offspring following ICSI if the oocyte is activated artificially [64, 66]. In addition, the putative activating sperm factor may become associated with the embryonic nuclei, as nuclei transferred from fertilized 1- and 2-cell stage mouse embryos induced intracellular calcium transient increases in unfertilized oocytes [67].

The action of the sperm activating factor is not highly species-specific because mouse oocytes are activated following injection of spermatozoa from the hamster, rabbit, pig, human and even fish [65]. Indeed, sperm of chicken, Xenopus and the flowering plant, Brassica campestris, contain a cytosolic soluble protein factor that triggers calcium oscillations in mouse oocytes $[68,69]$. The specificity of action of the sperm factor in triggering calcium oscillations in mammalian oocytes appears to be dependent upon the presence of maternal machinery. Tang et al. [70] found that prior exposure to sperm extract inhibited sperm factorinduced calcium oscillations in mouse oocytes, whereas prior exposure to an artificial calciumreleasing stimulus did not. This finding suggests that the maternal machinery responsible for producing the calcium oscillations at fertilization operates only once and is only inactivated by a 
sperm-derived component [70].

In an effort to characterize the active component of sperm, Parrington and coworkers [71] separated cytosolic extracts from boar sperm using three successive chromatographic columns with different separation properties. The fractions that released calcium from sea urchin egg homogenates also induced calcium oscillations following injection into mouse oocytes [71]. The calcium-releasing activity of boar sperm extract was found to be due to the action of a sperm-derived PLC, which hydrolyzed $\mathrm{PIP}_{2}$ to $\mathrm{InsP}_{3}$ [72]. Furthermore, recombinant PLCs and PLCs purified from boar brain, liver and kidney failed to release calcium in sea urchin egg homogenates or intact mouse oocytes, indicating that sperm PLC activity has distinct properties [73]. Other findings indicate that the putative sperm factor may generate $\mathrm{InsP}_{3}$ by stimulating PLC activity indirectly. A truncated form of the c-kit tyrosine kinase receptor, termed trkit, has been identified in the cytoplasm of mature mouse spermatozoa [74]. Injection of cellular extracts containing the tr-kit protein into mature mouse oocytes induced cortical granule exocytosis, resumption of meiosis and cleavage [75].

Although the precise nature and site of action of the activating signal at fertilization has not been resolved, the evidence in support of the sperm factor-mediated signalling pathway is compelling. The receptor-mediated signalling pathway that triggers calcium release in many other cellular processes has not been ruled out, but for a process as extraordinary as fertilization, where the sperm provides a unique delivery system for the activating signal, it seems reasonable to propose that a novel sperm factor mediates the response. Of the putative activating agents tested, the cytosolic factor present in sperm extract is the only candidate that can generate a pattern of intracellular calcium oscillations identical to that seen at fertilization [54]. Clearly, further studies are needed to confirm whether (i) the sperm factor-mediated signalling pathway functions in mammalian oocytes at fertilization and (ii) a single sperm contains enough sperm factor to trigger oocyte activation.

\section{The Role of Calcium at Activation}

The increase of intracellular calcium following fertilization is recognized as the primary signal responsible for the initiation of development (reviewed by [76]). This conviction is supported by experiments that either suppress the natural rise of calcium following fertilization, which inhibits oocyte activation, or raise the intracellular-free calcium concentration artificially, which stimulates oocyte activation. Events of oocyte activation that are regulated by calcium include the resumption of meiosis, cortical granule exocytosis, and possibly new protein synthesis [77]. Inhibition of calcium transient increases in fertilized mouse oocytes using the calcium chelator 1,2-bis(oaminophenoxy)ethane- $\mathrm{N}, \mathrm{N}, \mathrm{N}^{\prime}, \mathrm{N}^{\prime}$-tetraacetic acid (BAPTA) blocked cortical granule exocytosis and second polar body formation [3]. Other fertilization-associated events, such as zona pellucida modifications that result in a block to polyspermy, the decrease of histone H1 kinase activity, pronucleus formation, the recruitment of maternal mRNAs and post-translational modifications of proteins, were inhibited in mouse oocytes injected with a monoclonal antibody that binds to the Ins $\mathrm{P}_{3} \mathrm{Rs}$ and inhibits $\mathrm{InsP}_{3}$-induced calcium release [29]. Conversely, treatments that increase the concentration of intracellular-free calcium in the absence of sperm induce both early and late events of oocyte activation. The details of these treatments and their effects on mammalian oocyte activation are described later.

A number of studies indicate that the target effectors of calcium that are involved in the regulation of early and late events of oocyte activation include the calcium-dependent protein kinase $\mathrm{C}$ (PKC), calmodulin, and the calmodulindependent protein kinase II (CaMK $\mathrm{CI}_{\text {II }}$ (reviewed by [77]). In mouse oocytes, activation of PKC has been shown to induce cortical granule exocytosis [78] and initiate the structural changes required for second polar body formation [79]. Evidence also suggests that PKC is involved in regulating sperminduced calcium oscillations by exerting a negative feedback effect on calcium release [80]. Furthermore, PKC has been implicated in the resumption of meiosis [81], cortical granule exocytosis [82-84] and pronuclear formation [85, 86] in artificially activated oocytes. However, other evidence suggests that a different calciumdependent pathway, involving calmodulin and $\mathrm{CaMK}_{\mathrm{II}}$, is responsible for the resumption of meiosis at fertilization [87]. Calmodulin appears to be involved in the resumption of the cell cycle since 
meiotic progression and a decrease in histone $\mathrm{H} 1$ kinase activity were inhibited in fertilized mouse oocytes treated with the calmodulin antagonist W-7 [88]. However, W-7 treatment did not block cortical granule exocytosis, indicating a different pathway is involved in this activation-associated event [88]. In the same study, low concentrations of injected free calcium induced cortical granule exocytosis without triggering meiotic resumption, suggesting that the pathways have differing sensitivities to calcium [88]. A role for calmodulin in meiotic resumption is supported in studies of Xenopus eggs that found both cytostatic factor and maturation-promoting factor were inactivated by $\mathrm{CaMK}_{\text {II }}$ at fertilization [89].

\section{Maturation-Promoting Factor}

Meiosis is arrested in mature mammalian oocytes at the second metaphase (M-II) stage. Suspension of the oocyte cell cycle is maintained by a heterodimeric protein kinase called maturation (or M-phase) promoting factor (MPF), which is highly conserved [90]. The MPF protein complex consists of a regulatory subunit comprising of cyclin B [91] and a catalytic subunit comprising of a cyclindependent protein kinase that is the $34 \mathrm{kDa}$ product of the $c d c 2$ gene (p34 ${ }^{\mathrm{cdc} 2}$ ) [92, 93]. Activation of MPF is induced by cyclin B and requires phosphorylation of threonine residue 161 and dephosphorylation of tyrosine residue 15 (and threonine residue 14 in vertebrates) of the p34 $4^{\text {cdc2 }}$ subunit $[94,95]$.

In eukaryotic cells, the kinase activity of MPF is thought to initiate a series of reactions that result in nuclear envelope breakdown (NEBD), chromosome condensation and assembly of the metaphase spindle [90]. A major substrate of active MPF is the chromosomal packaging protein histone H1 [90]. Phosphorylation of histone H1 by cellular extracts forms the basis of an assay used to determine the level of MPF activity during meiosis and mitosis [90]. Changes in the level of MPF activity have been found to be similar during maturation of mouse [96, 97], rabbit [98], goat [99], cattle [100-102] and pig [103-107] oocytes. Numerous studies have found that the level of MPF activity is relatively low at the germinal vesicle stage and steadily increases as meiosis progresses to the first metaphase (M-I) stage. The level of MPF activity then decreases markedly at the anaphase-I and telophase-I stages, but increases again by the M-II stage to a level similar to that in M-I oocytes. Accumulation of newly synthesized cyclin B corresponds to an increase in MPF activity, while cyclin B degradation by ubiquitin-dependent proteolysis corresponds to a decrease in MPF activity $[107,108]$. In contrast, the level of p34 ${ }^{\text {cdc2 }}$ remains unchanged throughout meiosis $[96,107]$.

In M-II arrested oocytes, the elevated levels of MPF activity are maintained by a factor known as cytostatic factor (CSF), which prevents cyclin B degradation [90]. CSF activity has been shown to be associated with a number of different proteins including mitogen-activated protein kinase (MAP kinase or MAPK) [109], cyclin-dependent kinase 2 (cdk2) [110] and products of the raf-1 gene [111] and c-mos proto-oncogene [112]. As mentioned previously, CSF is inactivated by CaMK II in response to the sperm-induced intracellular calcium increase at fertilization [89]. Inactivation of CSF facilitates cyclin degradation, which decreases the levels of MPF activity in the oocyte, thereby initiating disassembly of the metaphase spindle [113].

MPF activity has been shown to return to basal levels following insemination in mouse [96], pig [114] and cattle [27] oocytes, within 3, 4 and $5 \mathrm{~h}$ respectively. Increasing the intracellular-free calcium concentration of mammalian oocytes artificially, using chemical or physical stimuli, has also been found to reduce the levels of MPF activity, often within one hour of treatment $[27,33$, 115-121].

\section{Artificial Activation}

In the absence of sperm, the concentration of intracellular-free calcium can be elevated in mammalian oocytes by many different treatments. Some of the treatments that have been used to induce an intracellular calcium increase in mouse, hamster, rabbit, cattle, pig and human oocytes are shown in Table 1. Cytoplasmic injection of solutions containing $\mathrm{Ca}^{2+}, \mathrm{InsP}_{3} \mathrm{R}$ agonists, $\mathrm{RyR}$ agonists or $\mathrm{G}$ protein activators, or incubation with alcohols, calcium ionophores, $\mathrm{Sr}^{2+}$ or thimerosal have all been shown to induce a transient intracellular calcium increase in mammalian oocytes. The infusion of extracellular $\mathrm{Ca}^{2+}$ or $\mathrm{InsP}_{3}$ 
Table 1. Artificial activation treatments that have been shown to induce intracellular calcium changes in mammalian oocytes

\begin{tabular}{|c|c|c|c|c|}
\hline Species & Reagent & Concentration & Application & Reference \\
\hline \multirow[t]{13}{*}{ Mouse } & $\mathrm{Ca}^{2+}$ & $\leq 0.9 \mathrm{mM}$ & Electric pulse & {$[123,129]$} \\
\hline & $\mathrm{Ca}^{2+}$ & $0.5 \mathrm{M}$ & Injection & [53] \\
\hline & $\mathrm{InsP}_{3}$ & $0.002-1 \mathrm{mM}$ & Injection & {$[11,53]$} \\
\hline & Adenophostin & $2-10 \mu \mathrm{M}$ & Injection & [66] \\
\hline & $\mathrm{Sr}^{2+}$ & $4.6-9.2 \mathrm{mM}$ & Incubation & [3] \\
\hline & Ethanol & $7-8.6 \%$ & Incubation & {$[140,155]$} \\
\hline & Butanol & $0.5 \%$ & Incubation & [155] \\
\hline & Acetylcholine & $50 \mu \mathrm{M}$ & Incubation & [153] \\
\hline & Thapsigargin & $10 \mu \mathrm{M}$ & Incubation & [12] \\
\hline & Ryanodine & $1 \mathrm{mM}$ & Incubation & [12] \\
\hline & A23187 & $5-10 \mu \mathrm{M}$ & Incubation & {$[3,140]$} \\
\hline & Ionomycin & $5-10 \mu \mathrm{M}$ & Incubation & {$[11,12]$} \\
\hline & Thimerosal & $1-200 \mu \mathrm{M}$ & Incubation & {$[11,153]$} \\
\hline \multirow[t]{5}{*}{ Hamster } & $\mathrm{InsP}_{3}$ & $0.08-240 \mu \mathrm{M}$ & Injection & {$[34,80]$} \\
\hline & GTP & 5-10 mM & Injection & [34] \\
\hline & GTPYS & $0.33-20 \mathrm{mM}$ & Injection & {$[34,80]$} \\
\hline & Thimerosal & $200 \mu \mathrm{M}$ & Incubation & [17] \\
\hline & Serotonin & $50 \mathrm{nM}$ & "Puffing" method & [158] \\
\hline \multirow[t]{6}{*}{ Rabbit } & $\mathrm{Ca}^{2+}$ & $0.1-1 \mathrm{mM}$ & Electric pulse & {$[122,124]$} \\
\hline & $\mathrm{Ca}^{2+}$ & $1.8 \mathrm{mM}$ & Injection & [32] \\
\hline & $\mathrm{InsP}_{3}$ & $5 \mu \mathrm{M}$ & Injection & {$[32,154]$} \\
\hline & $\mathrm{InsP}_{3} \mathrm{~S}_{3}$ & $500 \mu \mathrm{M}$ & Injection & [154] \\
\hline & GTPYS & 5-20 mM & Injection & [32] \\
\hline & Thimerosal & $400 \mu \mathrm{M}$ & Incubation & [154] \\
\hline \multirow[t]{7}{*}{ Pig } & $\mathrm{Ca}^{2+}$ & $100 \mu \mathrm{M}$ & Electric pulse & [5] \\
\hline & $\mathrm{Ca}^{2+}$ & $0.1 \mathrm{M}$ & Injection & [119] \\
\hline & $\mathrm{InsP}_{3}$ & $10-250 \mathrm{nM}$ & Injection & [25] \\
\hline & Ryanodine & $0.04-1.2 \mathrm{mM}$ & Injection & [25] \\
\hline & cADPR & $8-200 \mu \mathrm{M}$ & Injection & [25] \\
\hline & A23187 & $50 \mu \mathrm{M}$ & Incubation & {$[141,142]$} \\
\hline & Thimerosal & $200 \mu \mathrm{M}$ & Incubation & [152] \\
\hline \multirow[t]{11}{*}{ Cattle } & $\mathrm{Ca}^{2+}$ & $100 \mu \mathrm{M}$ & Electric pulse & [6] \\
\hline & Ethanol & $7 \%$ & Incubation & [139] \\
\hline & $\mathrm{InsP}_{3}$ & $0.05-190 \mu \mathrm{M}$ & Injection & {$[4,23,24,27,139,151]$} \\
\hline & $\mathrm{InsP}_{3} \mathrm{~S}_{3}$ & $500 \mu \mathrm{M}$ & Injection & [151] \\
\hline & GTP $\gamma S$ & $20 \mathrm{mM}$ & Injection & [151] \\
\hline & Ryanodine & $100-200 \mu \mathrm{M}$ & Injection & {$[23,24,27]$} \\
\hline & Caffeine & $10-20 \mathrm{mM}$ & Injection & [23] \\
\hline & cADPR & $4-8 \mu \mathrm{M}$ & Injection & {$[23,27]$} \\
\hline & A23187 & $10 \mu \mathrm{M}$ & Incubation & [139] \\
\hline & Ionomycin & $10 \mu \mathrm{M}$ & Incubation & [24] \\
\hline & Thimerosal & $100-200 \mu \mathrm{M}$ & Incubation & {$[4,139,151]$} \\
\hline Human & Thimerosal & $200 \mu \mathrm{M}$ & Incubation & [57] \\
\hline
\end{tabular}

into the oocyte cytoplasm, by exposing the oocyte to a direct current (DC) pulse of electricity, also increases the concentration of intracellular-free calcium.

Even though the amplitude, duration and spatiotemporal dynamics of the artificially induced calcium transient increases are unlike those observed at fertilization, they are still able to initiate both the early and late events associated with oocyte activation. In fact, many of the artificial activation treatments elicit only a single calcium rise, as opposed to the series of calcium oscillations induced by the fertilizing sperm.

\section{Calcium ions}

Measurement of the intracellular-free calcium concentration of oocytes with the fluorescent $\mathrm{Ca}^{2+}$ indicators, fura- 2 or flou-3, indicates that injection 
of $\mathrm{Ca}^{2+}$ into the cytoplasm of unfertilized oocytes produces a single, short-lived calcium transient increase, or spike, in the mouse [53] and rabbit [32]. The duration and amplitude of such calcium spikes are dependent on the concentration of $\mathrm{Ca}^{2+}$ in the injected solution [32]. Investigators have successfully generated a series of calcium oscillations in mouse oocytes by applying a series of $\mathrm{Ca}^{2+}$ iontophoretic injections to unfertilized oocytes, but they were unable to mimic the calcium oscillations seen after injection of sperm extract or $\mathrm{InsP}_{3}$ [53]. Surprisingly, however, a single injection of $\mathrm{Ca}^{2+}$ into the oocyte cytoplasm raises the intracellular-free calcium concentration sufficiently to trigger many of the events associated with normal oocyte activation. In porcine oocytes, a single injection of $\mathrm{Ca}^{2+}$ has been shown to induce cortical granule exocytosis, meiotic resumption, pronuclear formation, MPF inactivation, protein synthetic profile changes and parthenogenetic development to the blastocyst stage [119].

Another way of introducing $\mathrm{Ca}^{2+}$ into the oocyte cytoplasm is by making the oocyte plasma membrane permeable in the presence of $\mathrm{Ca}^{2+}$ with pulses of electricity. This method, often referred to as electrical activation, involves placing the oocytes between two electrodes, typically 0.5 to $1 \mathrm{~mm}$ apart, in a $\mathrm{Ca}^{2+}$-containing, sugar-based non-electrolyte solution of mannitol, sucrose or glucose, and delivering one or more DC pulses of electricity across the electrodes. The sugar molecules destabilize the plasma membrane while the electrical stimulus causes pores to form in the lipid bilayer, which facilitates the uptake of extracellular calcium by the oocyte. The membrane remains permeable to extracellular calcium for several minutes, during which time the pores presumably reseal $[122,123]$.

A single electric pulse has been shown to induce a calcium transient increase in mouse [123], rabbit [124], cattle [122] and pig [5] oocytes. The amplitude and decay time of the calcium spike is affected by the electrical field strength, the duration of the pulse, the concentration of $\mathrm{CaCl}_{2}$ in the pulsing medium and the pulsing medium itself [5, $123,124]$. A further source of variation in the oocyte uptake of extracellular calcium is the oocyte itself. The plasma membrane properties of the oocyte influence the formation of pores in the lipid bilayer and differ among species, change as the oocyte matures and ages, and are likely to be affected by the conditions that the oocyte is exposed to.

An analysis of electrically activated pig oocytes using dynamic video imaging revealed that the calcium rise is always initiated in the region adjacent to the positive electrode and advances through the oocyte in the form of a wave at a velocity of 5 to $10 \mu \mathrm{m} / \mathrm{sec}$ [5]. There are no subsequent calcium transient increases following the initial spike, as is seen at fertilization, unless additional electric pulses are applied [5]. These findings demonstrate that the calcium concentration change induced in oocytes by electric pulses is markedly different to that triggered by the fertilizing sperm. Despite this, the application of electric pulses to mammalian oocytes can induce both early and late events of oocyte activation.

Several investigators have demonstrated that cortical granule exocytosis, which is often referred to as the cortical reaction, is induced by electric pulses in porcine oocytes matured in vitro $[5,125-$ 127]. Transmission electron micrographs show that the ultrastructural changes associated with cortical granule loss following electrical activation are similar to those observed in fertilized oocytes [5]. The levels of MPF activity in cattle $[115,120]$ and pig $[33,116,117,119,128]$ oocyte extracts have also been found to decrease markedly following the application of electric pulses.

The formation of pronuclei is often used as an indicator of successful oocyte activation. Application of one or more electric pulses has been shown to induce meiotic resumption and pronuclear formation in mouse [123, 129], rabbit [8, 124], sheep [130], cattle [6, 131], pig [125, 126, 132134] and marmoset [135] oocytes. Furthermore, electrically activated rabbit [8], cattle [6] and pig $[126,132,133,136-138]$ oocytes undergo cleavage and parthenogenetic development to the blastocyst stage.

\section{Calcium ionophores}

Calcium ionophores, such as A23187 and ionomycin, are compounds that are capable of forming a complex with a calcium ion and transporting it through a biological membrane by a carrier-type mechanism. Intracellular-free calcium determinations using fura-2 or fluo-3 have demonstrated that incubation of mature mammalian oocytes with A23187 or ionomycin generates a single calcium transient increase $[3,11$, 
12, 24, 139-142]. Mouse [140] and cattle [139] oocytes treated with $10 \mu \mathrm{M}$ A23187 experience an intracellular calcium rise that is of greater amplitude and of longer duration than the first rise induced at fertilization. The precise mechanism of the ionophore-induced calcium increase is not well understood, because in some studies extracellular calcium was required to produce a calcium rise in the oocytes, while in others a calcium transient increase was observed in oocytes treated in $\mathrm{Ca}^{2+}$ free medium. The exact role of the internal calcium stores in the oocyte response to calcium ionophores is yet to be determined.

Treatment of oocytes with calcium ionophores also triggers the early and late events of oocyte activation. Cortical granule exocytosis [126, 127, 141-144] and zona pellucida modification, as assessed by the dissolution time of zonae in pronase and sperm penetrability [126, 141], have been observed in mammalian oocytes following treatment with A23187. In bovine oocytes, treatment with A23187 alone induces a decrease in the levels of MPF activity within $30 \mathrm{~min}$ [118]. Meiotic resumption and pronuclear formation have been observed in hamster [143, 144], cattle [131, 139] and pig [126, 132, 142, 145, 146] oocytes following treatment with A23187, with parthenogenetic development, as assessed by cleavage and blastocyst formation, also being reported [118, 126, 142, 145]. The concentration of A23187 and the duration of exposure to A23187 affect the efficiency of oocyte activation [131, 142]. In addition, the presence of extracellular calcium during treatment with A23187 increases the proportion of oocytes that develop parthenogenetically to the blastocyst stage [142].

Other studies have demonstrated that ionomycin induces the cortical reaction in rat oocytes [83, 84], MPF inactivation and meiotic resumption in cattle oocytes [121], and pronuclear formation in cattle [121] and sheep [130] oocytes. In response to ionomycin alone, bovine oocytes have also been shown to cleave and develop parthenogenetically to the blastocyst stage in an age-dependent manner [121].

\section{Ethanol}

Ethanol is thought to interact with cell membranes directly, polarizing the membrane and displacing $\mathrm{Ca}^{2+}$ from membrane phospholipids [147]. The addition of ethanol to the incubation medium of mouse [140] and cattle [139] oocytes, caused a rapid increase of intracellular calcium that was greater and of longer total duration than the first increase observed at fertilization. The optimum concentration of ethanol found to stimulate the resumption of meiosis in bovine oocytes matured in vitro was determined to be 7 percent when an exposure time of $7 \mathrm{~min}$ was used [148]. Similar ethanol treatments induced pronuclear formation in pig [132], sheep [130] and marmoset [135] oocytes. Development of early cleavage stage parthenotes has also been demonstrated following exposure of cattle [118, 148, 149] and marmoset [135] oocytes to ethanol. There are no reports, however, of oocytes treated with ethanol alone developing parthenogenetically to the blastocyst stage. Oocytes activated with ethanol require an additional treatment with inhibitors of protein synthesis or protein phosphorylation to form blastocysts [118].

\section{Thimerosal}

The sulfhydryl reagent, thimerosal, oxidizes sulfhydryl groups on proteins, which causes calcium concentration changes in mammalian oocytes by sensitizing $\mathrm{Ca}^{2+}$-induced $\mathrm{Ca}^{2+}$-release from InsP $\mathrm{P}_{3}$-regulated intracellular stores $[17,150]$. Whereas the majority of oocyte activation treatments induce a single intracellular calcium increase, incubation with thimerosal generates repetitive calcium transient increases. Following the addition of $200 \mu \mathrm{M}$ thimerosal to incubation media of mouse [11], cattle [4, 151], pig [152] and human [57] oocytes, a series of intracellular calcium oscillations was induced in which the initial calcium transient increase was of greater amplitude than the subsequent spikes. Although thimerosal treatment alone has been shown to induce zona pellucida modifications as assessed by zona hardening [153], resumption of meiosis and parthenogenetic development have not been reported. Examination of oocytes immunocytochemically has revealed that exposure to thimerosal completely destroys the meiotic spindle, apparently by oxidizing tubulin thiol groups, which is known to disrupt tubulin polymerization [153]. However, the effects of thimerosal on the metaphase spindle of oocytes can be reversed by the sulfhydryl-reducing reagent dithiothreitol (DTT), presumably by reducing the oxidized tubulin thiol groups [152, 153]. Pig 
oocytes sequentially incubated with thimerosal for $10 \mathrm{~min}$ and DTT for $30 \mathrm{~min}$ formed pronuclei and developed parthenogenetically to the blastocyst stage [152].

\section{Inositol 1,4,5-trisphosphate receptor agonists}

Agonists of the inositol 1,4,5-trisphosphate receptor $\left(\mathrm{InsP}_{3} \mathrm{R}\right)$, which functions as a calcium channel, increase the intracellular-free calcium concentration of oocytes by gating calcium release from the endoplasmic reticulum. Numerous studies have demonstrated that the injection or electroporation of $\mathrm{InsP}_{3}$ into the cytoplasm of mammalian oocytes induces an immediate, dosedependent intracellular calcium increase $[4,11,23$, $25,27,34,53,139,151,154]$. A single calcium spike is usually generated in response to $\operatorname{InsP}_{3}$, however, repeated spikes have been observed in mouse [11, 53] and hamster [34] oocytes at the higher injected concentrations examined. Intracytoplasmic injection of $\operatorname{InsP}_{3} \mathrm{R}$ agonists, such as $\mathrm{InsP}_{3} \mathrm{~S}_{3}$ [151, 154], thapsigargin [12] and adenophostin [66], evokes similar increases in the intracellular-free calcium concentration of mammalian oocytes. Some of the events of oocyte activation have also been reported following injection of $\mathrm{InsP}_{3} \mathrm{R}$ agonists, including zona pellucida modification, MPF inactivation, pronuclear formation and cleavage $[24,27,29,66]$.

\section{Ryanodine receptor agonists}

The ryanodine receptors (RyRs) are another major family of calcium channels that regulate the release of calcium from the endoplasmic reticulum in mammalian oocytes. Studies in mature mouse [12], cattle [23, 24, 27] and pig [25] oocytes have shown that a single calcium transient increase, similar in amplitude and duration to that induced by $\operatorname{Ins}_{3} \mathrm{R}$ agonists, can be generated following the intracytoplasmic injection of RyR agonists, such as ryanodine, caffeine and cADPR. In response to injection with ryanodine, cattle oocytes have also been reported to form pronuclei and cleave [24].

\section{Strontium ions}

Like calcium, strontium in solution exists as a divalent cation, which, in muscle cells, can be taken up by the sarcoplasmic reticulum (SR) via the ATPdependent transport system. In the presence of strontium, isolated SR have been shown to release calcium [3]. In $\mathrm{Ca}^{2+}$-free medium, mouse oocytes incubated with $1 \mathrm{mM} \mathrm{Sr}^{2+}$ have been found to undergo a single intracellular calcium increase [155], while multiple calcium transients were generated in the presence of $4.6 \mathrm{mM} \mathrm{Sr}^{2+}$ [3]. Evidence indicates that the effectiveness of $\mathrm{Sr}^{2+}$ in inducing calcium changes and the associated events of oocyte activation is reduced in $\mathrm{Ca}^{2+}$ containing media $[3,156,157]$. It is thought that $\mathrm{Sr}^{2+}$ activates oocytes by displacing bound calcium in the oocyte, thereby triggering calcium-induced calcium release (CICR) [157]. In support of this, the reducing agent dithiothreitol (DTT) has been found to act synergistically with $\mathrm{Sr}^{2+}$ to initiate a series of calcium spikes in mouse oocytes [153]. One of the actions of DTT is to stimulate the entry of divalent cations into the oocyte, which leads to the onset of CICR [153].

\section{$G$ protein activators}

Compounds that activate $G$ proteins, such as serotonin, acetylcholine and GTP analogues, can also induce increases in the intracellular-free calcium concentration of mammalian oocytes. Activation of $\mathrm{G}$ proteins mediates the generation of $\mathrm{InsP}_{3}$, which releases calcium from internal calcium stores. The results from studies on the effects of $G$ protein activators on oocyte activation lend considerable support to the theory that sperm triggers the calcium oscillations seen at fertilization via a $G$ protein-mediated pathway. Firstly, microinjection of $G$ protein activators into mouse [153], hamster [34, 80, 158], rabbit [32] and cattle [151] oocytes elicits intracellular calcium oscillations similar to those seen at fertilization. Secondly, G-protein antagonists that have been shown to block the effects of the GTP analogue, guanosine-5'-O-(3'-thiotriphosphate) (GTP $\gamma S)$, also inhibit fertilization $[34,80]$. Finally, microinjection of GTP $\gamma S$ into in vitro matured porcine oocytes has been shown to induce pronuclear formation and parthenogenetic development to the blastocyst stage [35, 119].

\section{Protein synthesis inhibitors}

Murine oocytes have been successfully activated by treatment with the protein synthesis inhibitor, cycloheximide [159]. Similar results have been obtained in human oocytes by incubation with puromycin, another protein synthesis inhibitor [160]. These compounds are thought to inhibit the synthesis of CSF, thereby reducing the level of MPF 
activity in the oocyte, which triggers the resumption of meiosis [148]. In pig and cattle oocytes, cycloheximide treatment alone failed to induce activation as effectively as stimuli that generated an intracellular calcium rise [132, 148, 149]. However, when used in combination with ethanol or electric pulses, cycloheximide treatment increased the percentage of oocytes that formed pronuclei and cleaved [132, 148, 149, 161].

\section{Protein kinase inhibitors}

Inhibition of protein kinases with compounds such as H-7, staurosporine and olomoucine has been reported to induce the resumption of meiosis in mammalian oocytes [125, 162-165]. Protein kinase inhibitors are thought to suppress the level of MPF activity in oocytes directly, by blocking the phosphorylating activity of p34 ${ }^{\text {cdc2 }}$, or indirectly, by inhibiting MAPK, which regulates p34 ${ }^{\text {cdc2 }}$ activity. In mouse oocytes, treatment with staurosporine resulted in the resumption of meiosis without the intracellular-free calcium concentration changing [165]. However, as with protein synthesis inhibitors, protein kinase inhibitors have been found to activate oocytes more effectively when combined with a calcium stimulus. For example, only very low rates of oocyte activation were obtained when unstimulated oocytes were treated with the protein kinase inhibitor 6dimethylaminopurine (6-DMAP) [118]. In contrast, incubation with 6-DMAP following exposure of oocytes to either calcium ionophore or ethanol resulted in high rates of parthenogenetic cleavage and blastocyst formation [118, 130].

\section{Activation of Nuclear Transfer Embryos}

To date, a number of different activation treatments have been used in nuclear transfer (NT) procedures that resulted in the births of live cloned offspring. "Dolly" the sheep, the first animal cloned from a somatic cell, was produced by activating the reconstructed NT embryo with a series of electric pulses [166]. Since the report of this remarkable achievement, other investigators have described similar electrical activation protocols to produce somatic cell clones of sheep [167-169], cattle [170-172], goats [173] and pigs [174]. As well as being an effective activation stimulus, electric pulses mediate fusion of the donor cell and the recipient cytoplast. By applying the fusion pulses in $\mathrm{Ca}^{2+}$-containing media, the same stimulus can induce activation. Simultaneous fusion and activation is therefore a feature of many NT procedures. Cloned offspring have also been obtained by using electric pulses to activate recipient cytoplasts prior to NT [167, 175] and reconstructed embryos following injection of donor nuclei [176].

Sequential incubations with the calcium ionophore, ionomycin, and the protein kinase inhibitor, 6-DMAP, is another activation treatment that has been used to produce cloned sheep [130], cattle [177-179], pigs [180,181] and goats [182]. Incubation with cycloheximide following exposure to ionomycin or electric pulses has also induced cattle [172, 183, 184], rhesus monkey [185] and mouflon [186] NT embryos to develop to term. Exposure to $\mathrm{Sr}^{2+}$, which induces multiple calcium transient increases in mouse oocytes, efficiently activated mouse NT embryos that yielded pups $[187,188]$. In cattle, other treatments that have been used to successfully activate somatic NT embryos include incubation with $7 \%$ ethanol $[189,190]$ and cooling to $10 \mathrm{C}$ following oocyte aging [191].

Enucleated metaphase-II stage oocytes have been used as recipient cytoplasts in the vast majority of NT procedures described. Upon transfer to such a cell, the donor nucleus is exposed to high levels of MPF activity, which induces nuclear envelope breakdown and premature chromosome condensation (reviewed by [192]). Therefore, cells in the $G_{0}$ or $G_{1}$ phases of the cell cycle are typically isolated to supply donor nuclei that maintain a diploid chromosomal complement following transfer (reviewed by [193]). It has been suggested that nuclear remodelling and reprogramming may be facilitated by prolonged exposure of transferred nuclei to oocyte cytoplasmic factors. In cattle, NT embryo development in vitro was significantly increased by delaying activation for 4 to $6 \mathrm{~h}$ after fusion [179]. However, given that simultaneous fusion and activation treatments have been used to clone offspring in a number of species, it can be argued that such a delay is not critical for successful reprogramming. Enucleated metaphase-II oocytes that were activated prior to NT have also been used as recipient cytoplasts in some NT procedures. Donor cells that are in the $S$ phase of the cell cycle maintain cell cycle synchrony with such a cell following transfer because the level of MPF activity 
has declined. Due to the poor efficiencies of current cloning procedures, the effects of activation treatments on the developmental competence of NT embryos are poorly understood.

\section{Strategies for Mimicking the Sperm-Induced Response}

Investigators have adopted two strategies for mimicking sperm-induced responses observed at fertilization. One approach involves exposing the oocyte to multiple calcium stimulations in an attempt to duplicate the discrete intracellular calcium changes that are triggered by the fertilizing sperm. The other approach involves exposing the oocyte to a single calcium stimulus and a subsequent treatment that inhibits MPF activity.

\section{Multiple calcium stimulations}

Parthenogenetic studies have demonstrated that the developmental competence of oocytes may be increased by applying multiple calcium stimulations which induce calcium changes similar to those observed at fertilization [6,8]. Oocytes exposed to electric pulse treatments that were repeated at intervals approximating the frequency of sperm-induced calcium spiking displayed an increased incidence of blastocyst formation compared with those exposed to a single stimulation [6, 138]. However, the further application of electrical pulses negated the beneficial effect that two or three stimulations imparted on pig [138] and cattle [6] oocytes, respectively. These findings suggest that the cumulative effect of the transient calcium increases was only beneficial below a threshold level, or that the application of too many electric pulses had a detrimental effect on some other aspect of oocyte viability, such as membrane integrity. The former proposal supports the theory that excessive calcium is detrimental to the function of cells [194].

Several studies have shown that the high level of active MPF, which maintains meiotic arrest in M-II oocytes, is reduced following artificial activation $[115,128,195,196]$. In sperm-penetrated oocytes, the level of active MPF stays lower than that at M-II for at least $16 \mathrm{~h}$ [115, 128, 197]. Collas et al. [115] reported that the MPF activity in electrically activated bovine oocytes was depleted further and suppressed for longer when multiple stimulations were administered compared with a single stimulation. This finding suggests that the first calcium increase initiated MPF inactivation and that the subsequent calcium increases maintained the suppression of MPF activity.

\section{Coupling a calcium stimulus with a treatment that inhibits MPF activity}

The other strategy adopted by many NT researchers is to couple a single calcium stimulus with a treatment that inhibits MPF activity [149, 198]. As already mentioned, such combined treatments have induced NT embryos to develop to term in a number of species. Cycloheximide has been used to inhibit MPF activity in electrically activated cattle [172, 183, 184], goat [199] and rhesus monkey [185] NT embryos and calcium ionophore-treated mouflon NT embryos [186]. Similarly, 6-DMAP has been used to suppress MPF activity in calcium ionophore-treated NT embryos of sheep [130], cattle [177-179], pigs [180, 181] and goats [182].

In porcine oocytes, a combined electrical activation and 6-DMAP treatment hastened the suppression of MPF activity compared with electrical activation alone [128]. Furthermore, MPF reactivation was delayed by 6-DMAP treatment such that the kinetics of MPF activity were similar to that of inseminated oocytes, which correlated with an increased incidence of parthenogenetic blastocyst formation [128]. Instead of attempting to mimic the calcium oscillations induced by the fertilizing sperm, this approach endeavours to duplicate a critical cell cycle event downstream of the initial sperm-induced response. However, 6DMAP is a broad-spectrum protein kinase inhibitor that may effect the phosphorylation state of proteins other than the catalytic subunit of MPFproteins that may be involved in the remodelling or reprogramming of donor nuclei. Therefore, it may be preferable to regulate MPF activity in NT embryos by using reagents that more specifically inhibit p34 ${ }^{\text {cdc2 }}$. There are a growing number of kinase inhibitors, including roscovitine, olomoucine and bohemine, which act by competing for the ATP-binding domain of cyclin-dependent protein kinases. Recently, specific inhibitors of cyclin-dependent protein kinases have been used in conjunction with a calcium-releasing stimulus to induce oocyte activation in cattle [200] and rhesus monkey oocytes [201]. 


\section{Conclusions}

Artificial activation treatments are unable to precisely duplicate the pattern of calcium oscillations that are induced by the fertilizing sperm. Although a single calcium stimulus induces many of the cellular events associated with oocyte activation, the application of multiple calcium stimulations may increase the developmental competence of the oocyte compared with a single stimulus. Evidence suggests that maternal machinery involved in the activation response is triggered by the sperm activating signal but not by artificially induced calcium-release. Isolation of the sperm cytosolic factor would undoubtedly enhance our understanding of oocyte activation and facilitate the development of improved artificial activation treatments. It is well established that meiotic resumption requires the inactivation of MPF. Premature reactivation of MPF following the application of a "weak" calcium-increasing stimulus may result in aberrant cell cycle progression. Currently, the best strategy for artificially mimicking the sperm-induced activation response in NT embryos of the domestic species may be to couple a single calcium stimulus with a treatment that suppresses MPF activity.

\section{References}

1. Whitaker M, Swann K. Lighting the fuse at fertilization. Development 1993; 117: 1-12.

2. Miyazaki $S$, Hashimoto $N$, Yoshimoto $Y$, Kishimoto T, Igusa Y, Hiramoto Y. Temporal and spatial dynamics of the periodic increase in intracellular free calcium at fertilization of golden hamster eggs. Dev Biol 1986; 118: 259-267.

3. Kline D, Kline JT. Repetitive calcium transients and the role of calcium in exocytosis and cell cycle activation in the mouse egg. Dev Biol 1992; 149: 8089.

4. Fissore RA, Dobrinsky JR, Balise JJ, Duby RT, Robl JM. Patterns of intracellular $\mathrm{Ca}^{2+}$ concentrations in fertilized bovine eggs. Biol Reprod 1992; 47: 960-969.

5. Sun FZ, Hoyland J, Huang X, Mason W, Moor RM. A comparison of intracellular changes in porcine eggs after fertilization and electroactivation. Development 1992; 115: 947-956.

6. Collas P, Fissore R, Robl JM, Sullivan EJ, Barnes FL. Electrically induced calcium elevation, activation, and parthenogenetic development of bovine oocytes. Mol Reprod Dev 1993; 34: 212-223.

7. Collas P, Robl JM. Factors affecting the efficiency of nuclear transplantation in the rabbit embryo. Biol Reprod 1990; 43: 877-884.

8. Ozil JP. The parthenogenetic development of rabbit oocytes after repetitive pulsatile electrical stimulation. Development 1990; 109: 117-127.

9. Vitullo AD, Ozil JP. Repetitive calcium stimuli drive meiotic resumption and pronuclear development during mouse oocyte activation. Dev Biol 1992; 151: 128-136.

10. Carroll J, Jones KT, Whittingham DG. $\mathrm{Ca}^{2+}$ release and the development of $\mathrm{Ca}^{2+}$ release mechanisms during oocyte maturation: A prelude to fertilization. Rev Reprod 1996; 1: 137-143.
11. Mehlmann LM, Kline D. Regulation of intracellular calcium in the mouse egg: Calcium release in response to sperm or inositol trisphosphate is enhanced after meiotic maturation. Biol Reprod 1994; 51: 1088-1098.

12. Jones KT, Carroll J, Whittingham DG. Ionomycin, thapsigargin, ryanodine, and sperm induced $\mathrm{Ca}^{2+}$ release increase during meiotic maturation of mouse oocytes. J Biol Chem 1995; 270: 6671-6677.

13. Jones KT, Carroll J, Merriman JA, Whittingham DG, Kono T. Repetitive sperm-induced $\mathrm{Ca}^{2+}$ transients in mouse oocytes are cell cycle dependent. Development 1995; 121: 3259-3266.

14. Berridge $\mathbf{M}$. Inositol triphosphate and calcium signalling. Nature 1993; 361: 315-325.

15. Fujiwara T, Nakada $K$, Shirakawa $H$, Miyazaki S. Development of inositol trisphosphate-induced calcium release mechanism during maturation of hamster oocytes. Dev Biol 1993; 156: 69-79.

16. He CL, Damiani P, Parys JB, Fissore RA. Calcium, calcium release receptors, and meiotic resumption in bovine oocytes. Biol Reprod 1997; 57: 1245-1255.

17. Miyazaki S, Shirakawa H, Nakada K, Honda $\mathbf{Y}$, Yazuki M, Nakade S, Mikoshiba K. Antibody to the inositol triphosphate receptor blocks thimersalenhanced $\mathrm{Ca}^{2+}$-induced $\mathrm{Ca}^{2+}$ release and $\mathrm{Ca}^{2+}$ oscillations in hamster eggs. FEBS 1992; 309: 180184.

18. Mehlmann LM, Mikoshiba K, Kline D. Redistribution and increase in cortical inositol 1,4,5trisphosphate receptors after meiotic maturation of the mouse oocyte. Dev Biol 1996; 180: 489-498.

19. Shiraishi K, Okada A, Shirakawa H, Nakanishi S, Mikoshiba K, Miyazaki S. Developmental changes in the distribution of the endoplasmic reticulum and inositol 1,4,5-trisphosphate receptors and the spatial pattern of $\mathrm{Ca}^{2+}$ release during maturation of hamster 
oocytes. Dev Biol 1995; 170: 594-606.

20. Coronado R, Morrissette J, Sukhareva M, Vaughan DM. Structure and function of ryanodine receptors. Am J Physiol 1994; 266: C1485-C1504.

21. Tsien RW, Tsien RY. Calcium channels, stores, and oscillations. Annu Rev Cell Biol 1990; 6: 715-760.

22. Swann K. Different triggers for calcium oscillations in mouse eggs involve a ryanodine-sensitive calcium store. Biochem J 1992; 287: 79-84.

23. Yue C, White KL, Reed WA, Bunch TD. The existence of inositol 1,4,5-trisphosphate and ryanodine receptors in mature bovine oocytes. Development 1995; 121: 2645-2654.

24. Yue C, White KL, Reed WA, King E. Localization and regulation of ryanodine receptor in bovine oocytes. Biol Reprod 1998; 58: 608-614.

25. Machaty Z, Funahashi H, Day BN, Prather RS. Developmental changes in the intracellular $\mathrm{Ca}^{2+}$ release mechanisms in porcine oocytes. Biol Reprod 1997; 56: 921-930.

26. Sousa M, Barros A, Tesarik J. The role of ryanodine-sensitive $\mathrm{Ca}^{2+}$ stores in the $\mathrm{Ca}^{2+}$ oscillation machine of human oocytes. Mol Hum Reprod 1996; 2: 265-272.

27. White KL, Yue CP. Intracellular receptors and agents that induce activation in bovine oocytes. Theriogenology 1996; 45: 91-100.

28. Miyazaki S, Yuzaki M, Nakada K, Shirakawa $\mathbf{H}$, Nakanishi S, Nakade S, Mikoshiba K. Block of $\mathrm{Ca}^{2+}$ wave and $\mathrm{Ca}^{2+}$ oscillation by antibody to the inositol 1,4,5-trisphosphate receptor in fertilized hamster eggs. Science 1992; 257: 251-255.

29. Xu Z, Kopf GS, Schultz RM. Involvement of inositol 1,4,5-trisphosphate-mediated $\mathrm{Ca}^{2+}$ release in early and late events of mouse egg activation. Development 1994; 120: 1851-1859.

30. Parrington J, Brind S, de Smedt $H$, Gangeswaran R, Lai FA, Wojcikiewicz R, Carroll J. Expression of inositol 1,4,5-trisphosphate receptors in mouse oocytes and early embryos: The type I isoform is upregulated in oocytes and downregulated after fertilization. Dev Biol 1998; 203: 451-461.

31. Miyazaki S. Repetitive calcium transients in hamster oocytes. Cell Calcium 1991; 12: 205-216.

32. Fissore RA, Robl JM. Mechanism of calcium oscillations in fertilized rabbit eggs. Dev Biol 1994; 166: 634-642.

33. Machaty Z, Mayes MA, Kovacs LG, Balatti PA, Kim JH, Prather RS. Activation of porcine oocytes via an exogenously introduced rat muscarinic M1 receptor. Biol Reprod 1997; 57: 85-91.

34. Miyazaki S. Inositol 1,4,5-trisphosphate-induced calcium release and guanine nucleotide-binding protein-mediated periodic calcium rises in golden hamster eggs. J Cell Biol 1988; 106: 345-353.

35. Machaty Z, Mayes MA, Prather RS. Parthenogenetic activation of porcine oocytes with
guanosine-5'-O-(3'-thiotriphosphate). Biol Reprod 1995; 52: 753-758.

36. Moore GD, Ayabe T, Visconti PE, Schultz RM, Kopf GS. Roles of heterotrimeric and monomeric G proteins in sperm-induced activation of mouse eggs. Development 1994; 120: 3313-3323.

37. Moore GD, Kopf GS, Schultz RM. Complete mouse egg activation in the absence of sperm by stimulation of an exogenous $G$ protein-coupled receptor. Dev Biol 1993; 159: 669-678.

38. Ciapa B, Epel D. A rapid change in phosphorylation on tyrosine accompanies fertilization of sea urchin eggs. FEBS Lett 1991; 295: 167-170.

39. Moore KL, Kinsey WH. Identification of an ablrelated protein tyrosine kinase in the cortex of the sea urchin egg: Possible role at fertilization. Dev Biol 1994; 164: 444-455.

40. Yim DL, Opresko LK, Wiley HS, Nuccitelli R. Highly polarized EGF receptor tyrosine kinase activity initiates egg activation in Xenopus. Dev Biol 1994; 162: 41-55.

41. Endo Y, Kopf GS, Schultz RM. Stage-specific changes in protein phosphorylation accompanying meiotic maturation of mouse oocytes and fertilization of mouse eggs. J Exp Zool 1986; 239: 401409.

42. Dupont G, McGuinness OM, Johnson MH, Berridge MJ, Borgese F. Phospholipase $C$ in mouse oocytes: Characterization of beta and gamma isoforms and their possible involvement in sperminduced $\mathrm{Ca}^{2+}$ spiking. Biochem J 1996; 316: 583-591.

43. Snell WJ, White JM. The molecules of mammalian fertilization. Cell 1996; 85: 629-637.

44. Almeida EA, Huovila AP, Sutherland AE, Stephens LE, Calarco PG, Shaw LM, Mercurio AM, Sonnenberg A, Primakoff P, Myles DG, White JM. Mouse egg integrin alpha 6 beta 1 functions as a sperm receptor. Cell 1995; 81: 1095-1104.

45. Evans JP, Schultz RM, Kopf GS. Mouse sperm-egg plasma membrane interactions: Analysis of roles of egg integrins and the mouse sperm homologue of PH-30 (fertilin) beta. J Cell Sci 1995; 108: 3267-3278.

46. Fusi FM, Vignali M, Busacca M, Bronson RA. Evidence for the presence of an integrin cell adhesion receptor on the oolemma of unfertilized human oocytes. Mol Reprod Dev 1992; 31: 215-222.

47. Fusi FM, Vignali M, Gailit J, Bronson RA. Mammalian oocytes exhibit specific recognition of the RGD (Arg-Gly-Asp) tripeptide and express oolemmal integrins. Mol Reprod Dev 1993; 36: 212219.

48. Blobel CP, Wolfsberg TG, Turck CW, Myles DG, Primakoff $\mathbf{P}$, White JM. A potential fusion peptide and an integrin ligand domain in a protein active in sperm-egg fusion. Nature 1992; 356: 248-252.

49. Clark EA, Brugge JS. Integrins and signal transduction pathways: The road taken. Science 
1995; 268: 233-239.

50. Iwao Y, Fujimura T. Activation of Xenopus eggs by RGD-containing peptides accompanied by intracellular $\mathrm{Ca}^{2+}$ release. Dev Biol 1996; 177: 558567.

51. Lawrence Y, Whitaker M, Swann K. Sperm-egg fusion is the prelude to the initial $\mathrm{Ca}^{2+}$ increase at fertilization in the mouse. Development 1997; 124: 233-241.

52. Swann K. A cytosolic sperm factor stimulates repetitive calcium increases and mimics fertilization in hamster eggs. Development 1990; 110: 1295-1302.

53. Swann K. $\mathrm{Ca}^{2+}$ oscillations and sensitization of $\mathrm{Ca}^{2+}$ release in unfertilized mouse eggs injected with a sperm factor. Cell Calcium 1994; 15: 331-339.

54. Parrington J, Swann K, Shevchenko VI, Sesay AK, Lai FA. Calcium oscillations in mammalian eggs triggered by a soluble sperm protein. Nature 1996; 379: 364-368.

55. Wu H, He CL, Fissore RA. Injection of a porcine sperm factor induces activation of mouse eggs. Mol Reprod Dev 1998; 49: 37-47.

56. Wu H, He CL, Fissore RA. Injection of a porcine sperm factor triggers calcium oscillations in mouse oocytes and bovine eggs. Mol Reprod Dev 1997; 46: 176-189.

57. Homa ST, Swann K. A cytosolic sperm factor triggers calcium oscillations and membrane hyperpolarizations in human oocytes. Hum Reprod 1994; 9: 2356-2361.

58. Stice SL, Robl JM. Activation of mammalian oocytes by a factor obtained from rabbit sperm. Mol Reprod Dev 1990; 25: 272-280.

59. Fissore RA, Gordo AC, Wu H. Activation of development in mammals - is there a role for a sperm cytosolic factor? Theriogenology 1998; 49: 4352.

60. Tesarik J, Sousa M, Testart J. Human oocyte activation after intracytoplasmic sperm injection. Hum Reprod 1994; 9: 511-518.

61. Palermo G, Joris H, Devroey $\mathbf{P}$, van Steirteghem AC. Pregnancies after intracytoplasmic injection of single spermatozoon into an oocyte. Lancet 1992; 340: 17-18.

62. Payne D, Flaherty SP, Jeffrey R, Warnes GM, Matthews CD. Successful treatment of severe male factor infertility in 100 consecutive cycles using intracytoplasmic sperm injection. Hum Reprod 1994; 9: 2051-2057.

63. van Steirteghem A, Liu J, Joris H, Nagy Z, Staessen C, Camus M, Wisanto A, van Assche E, Devroey P. Assisted fertilization by subzonal insemination and intracytoplasmic sperm injection. Reprod Fertil Dev 1994; 6: 85-89.

64. Kimura Y, Yanagimachi R. Mouse oocytes injected with testicular spermatozoa or round spermatids can develop into normal offspring. Development
1995; 121: 2397-2405.

65. Kimura Y, Yanagimachi R, Kuretake S, Bortkiewicz H, Perry AC, Yanagimachi H. Analysis of mouse oocyte activation suggests the involvement of sperm perinuclear material. Biol Reprod 1998; 58: 1407-1415.

66. Sato Y, Miyazaki S, Shikano T, Mitsuhashi N, Takeuchi H, Mikoshiba K, Kuwabara Y. Adenophostin, a potent agonist of the inositol 1,4,5trisphosphate receptor, is useful for fertilization of mouse oocytes injected with round spermatids leading to normal offspring. Biol Reprod 1998; 58: 867-873.

67. Kono T, Carroll J, Swann K, Whittingham DG. Nuclei from fertilized mouse embryos have calcium-releasing activity. Development 1995; 121: 1123-1128.

68. Dong JB, Tang TS, Sun FZ. Xenopus and chicken sperm contain a cytosolic soluble protein factor which can trigger calcium oscillations in mouse eggs. Biochem Biophys Res Commun 2000; 268: 947951.

69. Li ST, Huang XY, Sun FZ. Flowering plant sperm contains a cytosolic soluble protein factor which can trigger calcium oscillations in mouse eggs. Biochem Biophys Res Commun 2001; 287: 56-59.

70. Tang TS, Dong JB, Huang XY, Sun FZ. $\mathrm{Ca}^{2+}$ oscillations induced by a cytosolic sperm protein factor are mediated by a maternal machinery that functions only once in mammalian oocytes. Development 2000; 127: 1141-1150.

71. Parrington J, Jones KT, Lai A, Swann K. The soluble sperm factor that causes $\mathrm{Ca}^{2+}$ release from sea-urchin (Lytechinus pictus) egg homogenates also triggers $\mathrm{Ca}^{2+}$ oscillations after injection into mouse eggs. Biochem J 1999; 341: 1-4.

72. Jones KT, Cruttwell C, Parrington J, Swann K. A mammalian sperm cytosolic phospholipase C activity generates inositol trisphosphate and causes $\mathrm{Ca}^{2+}$ release in sea urchin egg homogenates. FEBS Lett 1998; 437: 297-300.

73. Jones KT, Matsuda M, Parrington J, Katan M, Swann K. Different $\mathrm{Ca}^{2+}$-releasing abilities of sperm extracts compared with tissue extracts and phospholipase $C$ isoforms in sea urchin egg homogenate and mouse eggs. Biochem J 2000; 346: 743-749.

74. Albanesi C, Geremia R, Giorgio M, Dolci S, Sette C, Rossi P. A cell- and developmental stage-specific promoter drives the expression of a truncated c-kit protein during mouse spermatid elongation. Development 1996; 122: 1291-1302.

75. Sette C, Bevilacqua A, Bianchini A, Mangia F, Geremia R, Rossi P. Parthenogenetic activation of mouse eggs by microinjection of a truncated c-kit tyrosine kinase present in spermatozoa. Development 1997; 124: 2267-2274. 
76. Ben Yosef D, Shalgi R. Early ionic events in activation of the mammalian egg. Rev Reprod 1998; 3: 96-103.

77. Ducibella T. Biochemical and cellular insights into the temporal window of normal fertilization. Theriogenology 1998; 49: 53-65.

78. Ducibella T, Kurasawa S, Duffy P, Kopf GS, Schultz RM. Regulation of the polyspermy block in the mouse egg: Maturation-dependent differences in cortical granule exocytosis and zona pellucida modifications by inositol 1,4,5-trisphosphate and an activator of protein kinase C. Biol Reprod 1993; 48: 1251-1257.

79. Gallicano GI, McGaughey RW, Capco DG. Activation of protein kinase $C$ after fertilization is required for remodeling the mouse egg into the zygote. Mol Reprod Dev 1997; 46: 587-601.

80. Swann K, Igusa Y, Miyazaki S. Evidence for an inhibitory effect of protein kinase C on G-proteinmediated repetitive calcium transients in hamster eggs. EMBO J 1989; 8: 3711-3718.

81. Colonna R, Tatone C, Francione A, Rosati F, Callaini G, Corda D, Di Francesco L. Protein kinase $\mathrm{C}$ is required for the disappearance of MPF upon artificial activation in mouse eggs. Mol Reprod Dev 1997; 48: 292-299.

82. Raz T, Eliyahu E, Yesodi V, Shalgi R. Profile of protein kinase $\mathrm{C}$ isozymes and their possible role in mammalian egg activation. FEBS Lett 1998; 431: 415418.

83. Raz T, Ben Yosef D, Shalgi R. Segregation of the pathways leading to cortical reaction and cell cycle activation in the rat egg. Biol Reprod 1998; 58: 94-102.

84. Raz T, Skutelsky E, Amihai D, Hammel I, Shalgi R. Mechanisms leading to cortical reaction in the mammalian egg. Mol Reprod Dev 1998; 51: 295-303.

85. Gallicano GI, Schwarz SM, McGaughey RW, Capco DG. Protein kinase C, a pivotal regulator of hamster egg activation, functions after elevation of intracellular free calcium. Dev Biol 1993; 156: 96-106.

86. Moses R, Kline D. Calcium-independent, meiotic spindle-dependent metaphase-to-interpahse transition in phorbol ester-treated mouse eggs. Dev Biol 1995; 171: 111-122.

87. Gallicano GI, Yousef MC, Capco DG. PKC - a pivotal regulator of early development. Bioessays 1997; 19: 29-36.

88. Xu Z, Lefevre L, Ducibella T, Schultz RM, Kopf GS. Effects of calcium-BAPTA buffers and the calmodulin antagonist W-7 on mouse egg activation. Dev Biol 1996; 180: 594-604.

89. Lorca T, Cruzalegui FH, Fesquet D, Cavadore JC, Mery J, Means A, Doree M. Calmodulin-dependent protein kinase II mediates inactivation of MPF and CSF upon fertilization of Xenopus eggs. Nature 1993; 366: 270-273.

90. Murray AW, Kirschner MW. Cyclin synthesis drives the early embryonic cell cycle. Nature 1989; 339: 275-280.

91. Gautier J, Minshull J, Lohka M, Giotzer M, Hunt T, Maller JL. Cyclin is a component of maturationpromoting factor from Xenopus. Cell 1990; 60: 487494.

92. Dunphy WG, Brizuela L, Beach D, Newport J. The Xenopus cdc2 protein is a component of MPF, a cytoplasmic regulator of mitosis. Cell 1988; 54: 423431.

93. Gautier J, Norbury C, Lohka M, Nurse P, Maller J. Purified maturation-promoting factor contains the product of a Xenopus homolog of the fission yeast cell cycle control gene $c d c 2$. Cell 1988; 54: 433-439.

94. King RW, Jackson PK, Kirschner MW. Mitosis in transition. Cell 1994; 79: 563-571.

95. Murray AW, Hunt T. Enzymes that control mitosis. In: Murray AW, Hunt T (eds.), The Cell Cycle: An Introduction. New York: W. H. Freeman; 1993: 4265.

96. Choi T, Aoki F, Mori M, Yamashita M, Nagahama Y, Kohmoto K. Activation of p34 ${ }^{\mathrm{cdc} 2}$ protein kinase activity in meiotic and mitotic cell cycles in mouse oocytes and embryos. Development 1991; 113: 789795.

97. Fulka JJ, Jung T, Moor RM. The fall of biological maturation promoting factor (MPF) and histone $\mathrm{H} 1$ kinase activity during anaphase and telophase in mouse oocytes. Mol Reprod Dev 1992; 32: 378-382.

98. Jelinkova L, Kubelka M, Motlik J, Guerrier P. Chromatin condensation and histone $\mathrm{H} 1$ kinase activity during growth and maturation of rabbit oocytes. Mol Reprod Dev 1994; 37: 210-215.

99. de Smedt V, Crozet N, Gall L. Morphological and functional changes accompanying the acquisition of meiotic competence in ovarian goat oocyte. J Exp Zool 1994; 269: 128-139.

100. Fissore RA, He CL, Vande Moude GF. Potential role of mitogen-activated protein kinase during meiosis resumption in bovine oocytes. Biol Reprod 1996; 55: 1261-1270.

101. Tatemoto H, Terada T. Activation of $\mathrm{p} 34^{\mathrm{cdc} 2}$ kinase around the meiotic resumption in bovine oocytes cultured in vitro. Theriogenology 1996; 45: 427-437.

102. Wu B, Ignotz G, Currie WB, Yang X. Dynamics of maturation-promoting factor and its constituent proteins during in vitro maturation of bovine oocytes. Biol Reprod 1997; 56: 253-259.

103. Christmann L, Jung T, Moor RM. MPF components and meiotic competence in growing pig oocytes. $\mathrm{Mol}$ Reprod Dev 1994; 38: 85-90.

104. Kubelka M, Rimkevicova Z, Guerrier P, Motlik J. Inhibition of protein synthesis affects histone H1 kinase, but not chromosome condensation activity, during the first meiotic division of pig oocytes. Mol Reprod Dev 1995; 41: 63-69.

105. Naito K, Toyoda Y. Fluctuation of histone H1 kinase 
activity during meiotic maturation in porcine oocytes. J Reprod Fertil 1991; 93: 467-473.

106. Naito K, Daen FP, Toyoda Y. Comparison of histone H1 kinase activity during meiotic maturation between two types of porcine oocytes matured in different media in vitro. Biol Reprod 1992; 47: 43-47.

107. Naito K. Intracellular regulation mechanism of porcine oocyte maturation. J Reprod Dev 1996; 42: j110-j109.

108. Glotzer M, Murray AW, Kirschner MW. Cyclin is degraded by the ubiquitin pathway. Nature 1991; 349: 132-138.

109. Haccard O, Sarcevic B, Lewellyn A, Hartley RS, Roy LM, Izumi T, Erikson E, Maller JL. Induction of metaphase arrest in cleaving Xenopus embryos by MAP kinase. Science 1993; 262: 1262-1265.

110. Gabrieli BG, Roy LM, Maller JL. Requirement for cdk2 in cytostatic factor-mediated metaphase II arrest. Science 1993; 259: 1766-1769.

111. MacNicol AM, Muslin AJ, Howards EL, Kikuchi A, MacNicol MC, Williams LT. Regulation of raf-1dependent signaling during early Xenopus development. Mol Cell Biol 1995; 15: 6686-6693.

112. Sagata N, Watanabe N, Vande Woude WG, Ikawa $\mathbf{Y}$. The c-mos proto-oncogene product is a cytostatic factor responsible for meiotic arrest in vertebrate eggs. Nature 1989; 342: 512-518.

113. Motlik J, Pavlok A, Kubelka M, Kalous J, Kalab P. Interplay between cdc2 kinase and MAP kinase pathway during maturation of mammalian oocytes. Theriogenology 1998; 49: 461-469.

114. Kikuchi K, Naito K, Daen FP, Izaike Y, Toyoda Y. Histone $\mathrm{H} 1$ kinase activity during in vitro fertilization of pig follicular oocytes matured in vitro. Theriogenology 1995; 43: 523-532.

115. Collas P, Sullivan EJ, Barnes FL. Histone H1 kinase activity in bovine oocytes following calcium stimulation. Mol Reprod Dev 1993; 34: 224-231.

116. Kikuchi K, Izaike Y, Noguchi J, Furukawa T, Daen FP, Naito K, Toyoda Y. Decrease of histone H1 kinase activity in relation to parthenogenetic activation of pig follicular oocytes matured and aged in vitro. J Reprod Fertil 1995; 105: 325-330.

117. Leal CLV, Liu L. Differential effects of kinase inhibitor and electrical stimulus on activation and histone $\mathrm{H} 1$ kinase activity in pig oocytes. Anim Reprod Sci 1998; 52: 51-61.

118. Liu L, Ju JC, Yang X. Parthenogenetic development and protein patterns of newly matured bovine oocytes after chemical activation. Mol Reprod Dev 1998; 49: 298-307.

119. Machaty Z, Funahashi H, Mayes MA, Day BN, Prather RS. Effects of injecting calcium chloride into in vitro-matured porcine oocytes. Biol Reprod 1996; 54: 316-322.

120. Soloy E, Srsen V, Pavlok A, Hyttel P, Thomsen PD,
Smith SD, Prochazka R, Kubelka M, Hoier R, Booth P, Motlik J, Greve T. Establishment of the block against sperm penetration in parthenogenetically activated bovine oocytes matured in vitro. J Reprod Fertil 1997; 111: 151-157.

121. Susko-Parrish JL, Leibfried Rutledge ML, Northey DL, Schutzkus V, First NL. Inhibition of protein kinases after an induced calcium transient causes transition of bovine oocytes to embryonic cycles without meiotic completion. Dev Biol 1994; 166: 729 739.

122. Collas P, Fissore R, Robl JM. Preparation of nuclear transplant embryos by electroporation. Anal Biochem 1993; 208: 1-9.

123. Rickords LF, White KL. Effect of electrofusion pulse in either electrolyte or nonelectrolyte fusion medium on subsequent murine embryonic development. Mol Reprod Dev 1992; 32: 259-264.

124. Fissore RA, Robl JM. Intracellular $\mathrm{Ca}^{2+}$ response of rabbit oocytes to electrical stimulation. Mol Reprod Dev 1992; 32: 9-16.

125. Prather RS, Mayes MA, Murphy CN. Parthenogenetic activation of pig eggs by exposure to protein kinase inhibitors. Reprod Fertil Dev 1997; 9: 539-544.

126. Wang WH, Abeydeera LR, Prather RS, Day BN. Functional analysis of activation of porcine oocytes by spermatozoa, calcium ionophore, and electrical pulse. Mol Reprod Dev 1998; 51: 346-353.

127. Wang WH, Sun QY, Hosoe M, Shioya Y, Day BN. Quantified analysis of cortical granule distribution and exocytosis of porcine oocytes during meiotic maturation and activation. Biol Reprod 1997; 56: 1376-1382.

128. Grupen CG, Mau JC, McIlfatrick SM, Maddocks S, Nottle MB. Effect of 6-dimethylaminopurine on electrically activated in vitro matured porcine oocytes. Mol Reprod Dev 2002; 62: 387-396.

129. Ozil JP, Swann K. Stimulation of repetitive calcium transients in mouse eggs. J Physiol 1995; 483: 331346.

130. Loi P, Ledda S, Fulka J, Jr., Cappai P, Moor RM. Development of parthenogenetic and cloned ovine embryos: Effect of activation protocols. Biol Reprod 1998; 58: 1177-1187.

131. Ware CB, Barnes FL, Maiki Laurila M, First NL. Age dependence of bovine oocyte activation. Gamete Res 1989; 22: 265-275.

132. Cha SK, Kim NH, Lee SM, Baik CS, Lee HT, Chung KS. Effect of cytochalasin B and cycloheximide on the activation rate, chromosome constituent and in vitro development of porcine oocytes following parthenogenetic stimulation. Reprod Fertil Dev 1997; 9: 441-446.

133. Kure-bayashi S, Miyake M, Katayama M, Miyano T, Kato S. Development of porcine blastocysts from in vitro-matured and activated haploid and diploid 
oocytes. Theriogenology 1996; 46: 1027-1036.

134. Prather RS, Eichen PA, Nicks DK, Peters MS. Artificial activation of porcine oocytes matured in vitro. Mol Reprod Dev 1991; 28: 405-409.

135. Marshall VS, Wilton LJ, Moore HD. Parthenogenetic activation of marmoset (Callithrix jacchus) oocytes and the development of marmoset parthenogenones in vitro and in vivo. Biol Reprod 1998; 59: 1491-1497.

136. Jolliff WJ, Prather RS. Parthenogenic development of in vitro-matured, in vivo-cultured porcine oocytes beyond blastocyst. Biol Reprod 1997; 56: 544-548.

137. Nagashima H, Ashman RJ, Nottle MB. Nuclear transfer of porcine embryos using cryopreserved delipated blastomeres as donor nuclei. Mol Reprod Dev 1997; 48: 339-343.

138. Grupen CG, Verma PJ, Du ZT, McIlfatrick SM, Ashman RJ, Nottle MB. Activation of in vivo- and in vitro-derived porcine oocytes by using multiple electrical pulses. Reprod Fertil Dev 1999; 11: 457-462.

139. Nakada K, Mizuno J. Intracellular calcium responses in bovine oocytes induced by spermatozoa and by reagents. Theriogenology 1998; 50: 269-282.

140. Shiina Y, Kaneda M, Matsuyama K, Tanaka K, Hiroi M, Doi K. Role of the extracellular $\mathrm{Ca}^{2+}$ on the intracellular $\mathrm{Ca}^{2+}$ changes in fertilized and activated mouse oocytes. J Reprod Fertil 1993; 97: 143-150.

141. Wang WH, Machaty Z, Abeydeera LR, Prather RS, Day BN. Parthenogenetic activation of pig oocytes with calcium ionophore and the block to sperm penetration after activation. Biol Reprod 1998; 58: 1357-1366.

142. Wang WH, Machaty Z, Ruddock N, Abeydeera LR, Boquest AC, Prather RS, Day BN. Activation of porcine oocytes with calcium ionophore: Effects of extracellular calcium. Mol Reprod Dev 1999; 53: 99107.

143. Hoshi K, Yanagida K, Sato A. Pretreatment of hamster oocytes with $\mathrm{Ca}^{2+}$ ionophore to facilitate fertilization by ooplasmic micro-injection. Hum Reprod 1992; 7: 871-875.

144. Steinhardt RA, Epel D, Carroll EJJ, Yanagimachi R. Is calcium ionophore a universal activator for unfertilized eggs? Nature 1974; 252: 41-43.

145. Funahashi H, Cantley TC, Stumpf TT, Terlouw SL, Day BN. In vitro development of in vitro-matured porcine oocytes following chemical activation or in vitro fertilization. Biol Reprod 1994; 50: 1072-1077.

146. Hagen DR, Prather RS, First NL. Response of porcine oocytes to electrical and chemical activation during maturation in vitro. Mol Reprod Dev 1991; 28: 70-73.

147. Whittingham D. Parthenogenesis in mammals, In: Finn C (ed.), Oxford Reviews of Reproductive Biology. Oxford: Clarendon Press; 1980: 205-231.

148. Yang X, Presicce GA, Moraghan L, Jiang SE, Foote
RH. Synergistic effect of ethanol and cycloheximide on activation of freshly matured bovine oocytes. Theriogenology 1994; 41: 395-403.

149. Presicce GA, Yang X. Parthenogenetic development of bovine oocytes matured in vitro for $24 \mathrm{~h}$ and activated by ethanol and cycloheximide. Mol Reprod Dev 1994; 38: 380-385.

150. Swann K. Thimerosal causes calcium oscillations and sensitizes calcium-induced calcium release in unfertilized hamster eggs. FEBS 1991; 278: 175-178.

151. Fissore RA, Pinto Correia C, Robl JM. Inositol trisphosphate-induced calcium release in the generation of calcium oscillations in bovine eggs. Biol Reprod 1995; 53: 766-774.

152. Machaty Z, Wang WH, Day BN, Prather RS. Complete activation of porcine oocytes induced by the sulfhydryl reagent, thimerosal. Biol Reprod 1997; 57: 1123-1127.

153. Cheek TR, McGuinness OM, Vincent C, Moreton RB, Berridge MJ, Johnson MH. Fertilisation and thimerosal stimulate similar calcium spiking patterns in mouse oocytes but by separate mechanisms. Development 1993; 119: 179-189.

154. Fissore RA, Robl JM. Sperm, inositol trisphosphate, and thimerosal-induced intracellular $\mathrm{Ca}^{2+}$ elevations in rabbit eggs. Dev Biol 1993; 159: 122-130.

155. Cuthbertson KSR, Whittingham DG, Cobbold PK. Free $\mathrm{Ca}^{2+}$ increases in exponential phases during mouse oocyte maturation. Nature 1981; 294: 754-757.

156. Fraser LR. Strontium supports capacitation and the acrosome reaction in mouse sperm and rapidly activates mouse eggs. Gamete Res 1987; 18: 363-374.

157. Whittingham DH, Siracusa G. The involvement of calcium in the activation of mammalian oocytes. Exp Cell Res 1978; 113: 311-317.

158. Miyazaki S, Katayama Y, Swann K. Synergistic activation by serotonin and GTP analogue and inhibition by phorbol ester of cyclic $\mathrm{Ca}^{2+}$ rises in hamster eggs. J Physiol 1990; 426: 209-227.

159. Siracusa G, Whittingham DG, Molinaro $\mathbf{M}$, Vivarelli E. Parthenogenic activation of mouse oocytes induced by inhibitors of protein synthesis. $J$ Embryol Exp Morphol 1978; 43: 157-166.

160. Balakier H, Casper RF. Experimentally induced parthenogenetic activation of human oocytes. Hum Reprod 1993; 8: 740-743.

161. Nussbaum DJ, Prather RS. Differential effects of protein synthesis inhibitors on porcine oocyte activation. Mol Reprod Dev 1995; 41: 70-75.

162. Lee J, Hata K, Miyano T, Yamashita M, Dai YF, Moor RM. Tyrosine phosphorylation of P34(Cdc2) in metaphase II-arrested pig oocytes results in pronucleus formation without chromosome segregation. Mol Reprod Dev 1999; 52: 107-116.

163. Mayes M, Stogsdill P, Prather R. Parthenogenetic activation of pig oocytes by protein kinase inhibition. Biol Reprod 1995; 53: 270-275. 
164. Rickords L, Peters M, Stumpf T, Prather R. Effect of the protein kinase $\mathrm{C}$ inhibitor staurosporine on oocyte activation of in vitro matured porcine oocytes. Biol Reprod 1992; 46 (suppl 1): 82 (abstract 125).

165. Rickords L, Prather R, Kovar D. Staurosporine induces pronuclear formation but does not elicit a rise in intracellular calcium in mouse oocytes. Biol Reprod 1995; 52 (suppl 1): 174 (abstract 470).

166. Wilmut I, Schnieke AE, McWhir J, Kind AJ, Campbell KH. Viable offspring derived from fetal and adult mammalian cells. Nature 1997; 385: 810813.

167. Campbell KH, McWhir J, Ritchie WA, Wilmut I. Sheep cloned by nuclear transfer from a cultured cell line. Nature 1996; 380: 64-66.

168. Schnieke AE, Kind AJ, Ritchie WA, Mycock K, Scott AR, Ritchie M, Wilmut I, Colman A, Campbell KH. Human factor IX transgenic sheep produced by transfer of nuclei from transfected fetal fibroblasts. Science 1997; 278: 2130-2133.

169. Wells DN, Misica PM, Day TA, Tervit HR. Production of cloned lambs from an established embryonic cell line: A comparison between in vivoand in vitro-matured cytoplasts. Biol Reprod 1997; 57: 385-393.

170. Kato Y, Tani T, Sotomaru Y, Kurokawa K, Kato J, Doguchi H, Yasue H, Tsunoda Y. Eight calves cloned from somatic cells of a single adult. Science 1998; 282: 2095-2098.

171. Kato Y, Tani T, Tsunoda Y. Cloning of calves from various somatic cell types of male and female adult, newborn and fetal cows. J Reprod Fertil 2000; 120: 231-237.

172. Kubota C, Yamakuchi H, Todoroki J, Mizoshita K, Tabara N, Barber M, Yang X. Six cloned calves produced from adult fibroblast cells after long-term culture. Proc Nat Acad Sci USA 2000; 97: 990-995.

173. Baguisi A, Behboodi E, Melican DT, Pollock JS, Destrempes MM, Cammuso C, Williams JL, Nims SD, Porter CA, Midura P, Palacios MJ, Ayres SL, Denniston RS, Hayes ML, Ziomek CA, Meade HM, Godke RA, Gavin WG, Overstrom EW, Echelard Y. Production of goats by somatic cell nuclear transfer. Nat Biotechnol 1999; 17: 456-461.

174. Polejaeva IA, Chen SH, Vaught TD, Page RL, Mullins J, Ball S, Dai YF, Boone J, Walker S, Ayares DL, Colman A, Campbell KHS. Cloned pigs produced by nuclear transfer from adult somatic cells. Nature 2000; 407: 86-90.

175. Loi P, Boyazoglu S, Gallus M, Ledda S, Naitana S, Wilmut I, Cappai P, Casu S. Embryo cloning in sheep: Work in progress. Theriogenology 1997; 48: 110.

176. Onishi A, Iwamoto M, Akita T, Mikawa S, Takeda K, Awata T, Hanada H, Perry ACF. Pig cloning by microinjection of fetal fibroblast nuclei. Science 2000;
289: 1188-1190.

177. Cibelli JB, Stice SL, Golueke PJ, Kane JJ, Jerry J, Blackwell C, Ponce de Leon FA, Robl JM. Cloned transgenic calves produced from nonquiescent fetal fibroblasts. Science 1998; 280: 1256-1258.

178. Wells DN, Misica PM, Tervit HR. Production of cloned calves following nuclear transfer with cultured adult mural granulosa cells. Biol Reprod 1999; 60: 996-1005.

179. Wells DN, Misica PM, Tervit HR, Vivanco WH. Adult somatic cell nuclear transfer is used to preserve the last surviving cow of the Enderby Island cattle breed. Reprod Fertil Dev 1998; 10: 369378.

180. Betthauser J, Forsberg E, Augenstein M, Childs L, Eilertsen K, Enos J, Forsythe T, Golueke P, Jurgella G, Koppang R, Lesmeister T, Mallon K, Mell G, Misica P, Pace M, Pfister-Genskow M, Strelchenko N, Voelker G, Watt S, Thompson S, Bishop M. Production of cloned pigs from in vitro systems. Nat Biotechnol 2000; 18: 1055-1059.

181. Boquest AC, Grupen CG, Harrison SJ, MacIlfatrick SM, Ashman RJ, d'Apice AJF, Nottle MB. Production of cloned pigs from cultured fetal fibroblast cells. Biol Reprod 2002; 66: 1283-1287.

182. Keefer CL, Keyston R, Lazaris A, Bhatia B, Begin I, Bilodeau AS, Zhou FJ, Kafidi N, Wang B, Baldassarre H, Karatzas CN. Production of cloned goats after nuclear transfer using adult somatic cells. Biol Reprod 2002; 66: 199-203.

183. Kishi M, Itagaki Y, Takakura R, Imamura M, Sudo T, Yoshinari M, Tanimoto M, Yasue H, Kashima N. Nuclear transfer in cattle using colostrum-derived mammary gland epithelial cells and ear-derived fibroblast cells. Theriogenology 2000; 54: 675-684.

184. Kasinathan P, Knott JG, Wang Z, Jerry DJ, Robl JM. Production of calves from G1 fibroblasts. Nat Biotechnol 2001; 19: 1176-1178.

185. Meng L, Ely JJ, Stouffer RL, Wolf DP. Rhesus monkey produced by nuclear transfer. Biol Reprod 1997; 57: 454-459.

186. Loi P, Ptak G, Barboni B, Fulka JJ, Cappai P, Clinton $\mathbf{M}$. Genetic rescue of an endangered mammal by cross-species nuclear transfer using post-mortem somatic cells. Nat Biotechnol 2001; 19: 962-964.

187. Wakayama T, Perry AC, Zuccotti M, Johnson KR, Yanagimachi R. Full-term development of mice from enucleated oocytes injected with cumulus cell nuclei. Nature 1998; 394: 369-374.

188. Wakayama T, Rodriguez I, Perry ACF, Yanagimachi R, Mombaerts P. Mice cloned from embryonic stem cells. Proc Nat Acad Sci USA 1999; 96: 14984-14989.

189. Zakhartchenko V, Durcova-Hills G, Stojkovic M, Schernthaner W, Prelle K, Steinborn R, Muller M, Brem G, Wolf E. Effects of serum starvation and 
recloning on the efficiency of nuclear transfer using bovine fetal fibroblasts. J Reprod Fertil 1999; 115: 325331.

190. Zakhartchenko V, Alberio R, Stojkovic M, Prelle K, Schernthaner W, Stojkovic P, Wenigerkind $H$, Wanke R, Duchler M, Steinborn R, Mueller M, Brem G, Wolf E. Adult cloning in cattle: Potential of nuclei from a permanent cell line and from primary cultures. Mol Reprod Dev 1999; 54: 264-272.

191. Vignon X, LeBourhis D, Chesne P, Marchal J, Heyman Y, Renard JP. Development of bovine nuclear transfer embryos reconstituted with quiescent and proliferative skin fibroblasts. Theriogenology 1999; 51: 216 (Abstract).

192. Fulka JJ, Loi P, Ledda S, Moor RM, Fulka J. Nucleus transfer in mammals: How the oocyte cytoplasm modifies the transferred nucleus. Theriogenology 2001; 55: 1373-1380.

193. Campbell KH, Loi P, Otaegui PJ, Wilmut I. Cell cycle co-ordination in embryo cloning by nuclear transfer. Rev Reprod 1996; 1: 40-46.

194. Izant JG. The role of calcium ions during mitosis. Calcium participates in the anaphase trigger. Chromosoma 1983; 88: 1-10.

195. Collas P, Chang T, Long C, Robl JM. Inactivation of histone $\mathrm{H} 1$ kinase by $\mathrm{Ca}^{2+}$ in rabbit oocytes. Mol Reprod Dev 1995; 40: 253-258.
196. Liu L, Ju JC, Yang X. Differential inactivation of maturation-promoting factor and mitogen-activated protein kinase following parthenogenetic activation of bovine oocytes. Biol Reprod 1998; 59: 537-545.

197. Liu L, Yang X. Interplay of maturation-promoting factor and mitogen-activated protein kinase inactivation during metaphase-to-interphase transition of activated bovine oocytes. Biol Reprod

00398.Szollosi MS, Kubiak JZ, Debey P, de Pennart H, Szollosi D, Maro B. Inhibition of protein kinases by 6-dimethylaminopurine accelerates the transition to interphase in activated mouse oocytes. J Cell Sci 1993; 104: 861-872.

199. Yong Z, Yuqiang L. Nuclear-cytoplasmic interaction and development of goat embryos reconstructed by nuclear transplantation: Production of goats by serially cloning embryos. Biol Reprod 1998; 58: 266-269.

200. Alberio R, Kubelka M, Zakhartchenko V, Hajduch M, Wolf E, Motlik J. Activation of bovine oocytes by specific inhibition of cyclin-dependent kinases. Mol Reprod Dev 2000; 55: 422-432.

201. Mitalipov SM, Nusser KD, Wolf DP. Parthenogenetic activation of rhesus monkey oocytes and reconstructed embryos. Biol Reprod 2001; 65: 253-259. 